Universidad de Lima

Escuela de Posgrado

Maestría en Derecho Empresarial



\title{
ASPECTOS CONTROVERTIDOS DEL RECARGO AL CONSUMO DESDE UNA PERSPECTIVA LABORAL Y TRIBUTARIA
}

Trabajo de investigación para optar el Grado Académico de Maestro en Derecho Empresarial

\section{Henry Jan Brun Herbozo}

Código 19960185

\author{
Lima - Perú \\ Marzo de 2016
}









\section{ASPECTOS CONTROVERTIDOS DEL RECARGO AL CONSUMO DESDE UNA PERSPECTIVA LABORAL Y TRIBUTARIA}




\section{TABLA DE CONTENIDO}

INTRODUCCIÓN ........................................................ 1

CAPÍTULO I: EL RECARGO AL CONSUMO .............................. 3

1.1 Antecedentes.........................................................

1.1.1 El primer antecedente del recargo al consumo - El Convenio Colectivo de 1945. 3

1.1.2 El recargo al consumo del 10\% regulado por la Ley $\mathrm{N}^{\circ} 14701$ (1963 1980).

1.1.3 Norma de regularización del recargo del $10 \%$ regulado por la Ley $\mathrm{N}^{\circ}$



1.1.4 El recargo al consumo regulado por el Decreto Ley № 23128 (1980 1988).

1.1.5 El recargo único del 13\% regulado por la Ley $\mathrm{N}^{\circ} 24896$ (1988 - 1992)



1.2 Consideraciones sobre el actual recargo al consumo (1992- actualidad)....9

1.2.1 Consideraciones preliminares................................. 9

1.2.2 Características del recargo al consumo .......................... 10

1.2.2.1 Establecimientos facultados a implementar el cobro del recargo al consumo ........................................................... 10



1.2.2.3 Porcentaje del recargo al consumo ...............................12

1.2.2.4 Forma de cálculo del recargo al consumo $\ldots \ldots \ldots \ldots \ldots \ldots \ldots \ldots \ldots . \ldots 12$

1.2.2.5 Forma de distribución del recargo al consumo .................... 13

1.2.2.6 Plazo para el pago del recargo al consumo ......................... 14

1.2.3 El recargo al consumo en el Código de Protección y Defensa del



CAPITULO II: ASPECTOS LABORALES DEL RECARGO AL CONSUMO ...17

2.1 Desarrollo conceptual del recargo al consumo ....................... 17

2.1.1 Conceptos remunerativos ........................................ 17

2.1.2 Conceptos no remunerativos ...................................... 19 
2.1.2.1 Las condiciones de trabajo 20

2.1.2.2 Otros conceptos no remunerativos ............................. 21

2.2 Naturaleza jurídica del recargo al consumo ............................ 22



2.4 Competencia jurisdiccional de los juzgados laborales en materia del recargo al consumo 25

\section{CAPITULO III: ASPECTOS IMPOSITIVOS DEL RECARGO AL CONSUMO}

3.1 Aspectos impositivos del recargo al consumo para los trabajadores........ 26

3.1.1 Recargo al Consumo e Impuesto a la Renta de quinta categoría......... 26

3.1.1.1 Afectación del recargo al Impuesto a la Renta de quinta categoría..... 26

3.1.1.2 Forma de pago del Impuesto a la Renta de quinta categoría .......... 28

3.1.2 Recargo al consumo y aportaciones sociales......................... 31

3.2 Aspectos impositivos para los establecimientos de hospedaje y restaurantes 33

3.2.1 Recargo al consumo e Impuesto a la Renta empresarial....................... 33

3.1.1.2 Afectación del recargo al consumo al Impuesto a la Renta empresarial 36

3.1.1.3 Desnaturalización del recargo y su afectación al Impuesto a la Renta empresarial 42

3.2.2 Recargo al consumo e Impuesto General a las Ventas. 42

3.1.1.4 Aplicación del recargo al consumo y determinación de la base imponible del Impuesto General a las Ventas 45

3.1.1.5 Contingencias por la desnaturalización del recargo e Impuesto General a las Ventas 47

CONCLUSIONES ........................................................... 50












\section{INTRODUCCIÓN}

La Ley no siempre es sinónimo de Justicia. Y el reconocimiento legal de un derecho no siempre garantiza su satisfacción en la práctica. Esta afirmación puede verificarse con triste notoriedad en el reconocimiento y aplicación de los derechos laborales en el Perú. Como sabemos, nuestra legislación laboral contempla una serie de derechos a favor de los trabajadores, desde el beneficio económico por excelencia en una relación laboral, que es la remuneración, hasta beneficios que se han obtenido luego de muchos años de lucha por su reconocimiento, como los derechos de carácter colectivo a la sindicalización y a la huelga.

En cierta forma, el recargo al consumo forma parte de estos derechos a favor de los trabajadores, que se han obtenido luego de luchas y negociaciones para transformar lo que, originalmente, era una costumbre, a un derecho reconocido legalmente.

Lamentablemente, como hemos dicho, no siempre el reconocimiento legal de un derecho conlleva a su satisfacción en la práctica. Este es el caso del recargo al consumo.

Así, con varios antecedentes convencionales y normativos, en el Perú, el recargo al consumo encuentra su sustento legal vigente en el mes de diciembre de 1992, durante el gobierno del Presidente Alberto Fujimori Fujimori, con la entrada en vigencia del Decreto Ley $\mathrm{N}^{\circ}$ 25988, que aprobó la "Ley de Racionalización del Sistema Tributario Nacional y de Eliminación de Privilegios y Sobrecostos" -que además de reorganizar el régimen tributario existente hasta ese entonces- estableció un beneficio en favor de los trabajadores de establecimientos de hospedaje y restaurantes calculado sobre la base hasta el $13 \%$ aplicable sobre el importe de las ventas de dichos establecimientos.

Según su norma de creación, el cobro y el porcentaje de este nuevo "recargo al consumo" debe ser establecido por acuerdo entre los establecimientos de hospedaje y restaurantes y sus trabajadores, regulándose además que dicho beneficio no tendría carácter remunerativo ni se encontraría afecto a contribuciones de seguridad social, indemnizaciones beneficios laborales o compensación alguna.

Es el caso que, habiendo transcurrido más de veinte años desde la entrada en vigencia de este nuevo "recargo a consumo", hemos identificado la necesidad de dar 
solución a los vacíos normativos contenidos en la ley de creación del recargo al consumo que generan una serie de contingencias tributarias y situaciones incertidumbre jurídica, tanto para las empresas que lo pagan por cuenta de los clientes como para los propios trabajadores que perciben o debieran percibir este beneficio económico.

Entre los principales problemas que se generan en la práctica por la implementación del recargo al consumo, destacan la indefinición en la forma de reparto del recargo al consumo entre los trabajadores, el mecanismo y la acción de cobranza que se debe seguir ante el incumplimiento en el pago por parte de los empleadores, el plazo para ejercitar la acción, la indefinición sobre la naturaleza remunerativa o no del recargo al consumo,la forma de pago del Impuesto a la Renta de quinta categoría, la posible acotación por parte de la Administración Tributaria en el Impuesto a la Renta empresarial y el Impuesto General a las Ventas (IGV) en los casos de incumplimiento en el pago del recargo a los trabajadores.

Expuesto lo anterior y para la resolución de los problemas planteados se parte de la premisa consistente en la naturaleza no remunerativa del recargo al consumo y las contingencias tributarias que originan para los sujetos involucrados por el hecho de desnaturalizar dicho beneficio como consecuencia de la no distribución a los trabajadores.

Por último y pese a las limitantes relacionadas a la poca información sistematizada sobre el tema, el presente trabajo de investigación pretende, en primer lugar, desarrollar cada uno de los aspectos involucrados en la regulación del recargo al consumo; en segundo lugar, plantear la problemática del recargo al consumo analizada desde la perspectiva tanto del Derecho Laboral como del Derecho Tributario y finalmente, dar solución a la problemática planteada inicialmente. 


\section{CAPÍTULO I: EL RECARGO AL CONSUMO}

\subsection{Antecedentes}

Establecer los orígenes de lo que hoy conocemos como "recargo al consumo" representa una labor complicada. Esto debido a que nuestra legislación adolece de una sistematización adecuada, sobre todo si se trata de disposiciones legales de larga data.

Pero lo que está claro es que el origen de la figura del recargo al consumo se encuentra en la costumbre de la denominada "propina", que se entregaba y entrega como un pago adicional al servicio facturado por establecimientos de hospedaje y de alimentos y bebidas, para recompensar el buen trato ofrecido por el personal de servicio, como mozos, botones, azafatas y similares.

Esta costumbre tiene, como uno de sus posibles orígenes, a la antigua Grecia, en la cual se acostumbraba dejar una parte de las bebidas que se ordenaban, de forma tal que el resto de bebida que quedaba en el vaso constituía la propina que se dejaba a favor del sirviente. De aquí el origen de la palabra propina, derivada del latín "propinare", que significa dar de beber.

Claro está, que en sus orígenes la propina tenía un carácter voluntario, es decir, era el cliente o consumidor quien decidía si dejaba una propina a la persona que lo atendía, como adicional al monto que pagaba por el servicio o consumo.

En la actualidad, muchos países mantienen a la propina como una costumbre, en tanto que otros, como el caso del Perú, optaron por internalizar esta propina en el precio e incluirlo en la legislación, con diversos tratamientos, según veremos.

\subsubsection{El primer antecedente del recargo al consumo - el convenio colectivo de $\mathbf{1 9 4 5}$}

Uno de los primeros antecedentes que hemos podido identificar sobre el recargo al consumo, es el resultado de una negociación colectiva llevada a cabo entre empleadores y trabajadores del ramo de establecimientos de hospedaje.

Es así que en 1945, se firmó un Convenio Colectivo que tuvo como parte de su contenido, el establecimiento de un recargo equivalente al $10 \%$ sobre los servicios prestados y que sería entregado en favor de los trabajadores. 
Este beneficio, entonces tuvo desde sus inicios un origen eminentemente laboral al ser producto de una negociación colectiva entre trabajadores de establecimientos de hospedaje y representantes de dichos establecimientos.

Como consecuencia de ello, en sus orígenes este recargo al servicio tuvo carácter remunerativo para los trabajadores, dado que la entrega de este beneficio representó en su momento un aumento salarial.

\subsubsection{El recargo al consumo del $10 \%$ regulado por la Ley $\mathrm{N}^{\circ} 14701(1963-1980)$}

Varios años después, en noviembre de 1963 durante el primer gobierno del Presidente Fernando Belaunde Terry, el Congreso de la República aprobó la Ley $\mathrm{N}^{\circ} 14701^{1}$ mediante la cual por primera vez se introdujo en nuestra legislación el concepto del recargo del $10 \%$ a cargo del consumidor sobre el importe de las facturas extendidas por los hoteles, restaurantes y ramos similares, teniendo por tenía finalidad la de servir para el pago de las indemnizaciones y la jubilación de los trabajadores.

La norma además reconoció de manera expresa que el recargo debía estar destinado a formar parte integrante del salario del trabajador, sin embargo, no debía formar parte de la base de cálculo para indemnizaciones, vacaciones y otros beneficios laborales. Adicionalmente, se reguló de manera expresa que dicho beneficio no debía estar sujeto a descuento alguno por parte del empleador.

En cuanto a la forma de distribución del recargo, ésta debía ser distribuido según acuerdo entre trabajadores y empleador y en caso que no se llegará a un acuerdo, debía ser el "Ministerio de Trabajo y Asuntos Indígenas" quien determinaría el reparto a que hubiera lugar en calidad de árbitro, siendo dicho fallo inapelable.

En este sentido y con la finalidad de evitar cualquier discrepancia relacionada al contenido del acuerdo de distribución, con buen criterio, la norma reguló la obligación de inscribir el acuerdo en un registro a cargo de la Dirección General del Trabajo.

\footnotetext{
${ }^{1}$ La Ley $\mathrm{N}^{\circ} 14701$ - "Disponiendo forme parte del salario para computar indemnizaciones y jubilación de los trabajadores en hoteles, restaurantes, etc. el recargo del 10\% que extiende el principal a cargo del consumidor", fue publicada el 115 de noviembre de 1963 y DEROGADA por la Disposición Final del Decreto Ley N²23128, publicada el 11 julio 1980.
} 
De otro lado, la ley reconoció también una serie de derechos y condiciones laborales a favor de los trabajadores de hoteles y restaurantes y que se resumen en lo siguiente:

- Regulación de remuneraciones, sueldos y salarios mínimos para los trabajadores del rubro.

- Prohibición de descontar de cualquier ingreso que reciba el trabajador las faltas, roturas, pérdidas y multas, salvo en determinados casos señalados por ley y previa justificación ante la autoridad de trabajo.

- Habilitación de lugares de descanso para el personal que labora después de las doce de la noche y no opte por retornar a su domicilio, además de abonarle gastos de movilidad y remuneraciones por trabajo nocturno.

- Proporcionar asiento y lugar adecuado a los trabajadores que reciban alimentación en sus centros de trabajo.

- Garantizar el retorno del trabajador al centro laboral en el caso de los establecimientos que laboran por temporada.

- Entrega de comida y cena en los centros de trabajo nocturno.

- Recibir, sin costo alguno para los trabajadores, uniformes y herramientas propias de su labor, así como recibir el lavado periódico de aquellos.

Podemos observar que este beneficio tuvo una naturaleza eminentemente remunerativa al reconocer que el recargo debía formar parte integrante del salario del trabajador, sin embargo, llama la atención que expresamente se haya regulado que no formaría parte de sus beneficios sociales.

\subsubsection{Norma de regularización del "recargo" del $10 \%$ regulado por la Ley $\mathrm{N}^{\circ}$ 16658 (1967 - 1980)}

En el año 1967, durante el primer gobierno del Presidente Fernando Belaunde Terry, el Congreso de la República aprobó la Ley $\mathrm{N}^{\circ} 16658^{2}$ mediante la cual modificó el

\footnotetext{
${ }^{2}$ Ley $\mathrm{N}^{\mathrm{o}} 16658$ - "Los hoteles, restaurantes y afines, regularizarán la aplicación del recargo del 3\% adicional al $10 \%$ de servicio sobre las facturas por alojamiento y consumo efectivamente pagadas por el consumidor" fue publicada el 12 de julio de 1967 y fue derogada por la Disposición Final del Decreto Ley $\mathrm{N}^{\circ} 23128$, publicado el 11 julio 1980.
} 
porcentaje del recargo -hasta entonces fijado en $10 \%$ - e incrementándolo en tres puntos porcentuales, estableciéndolo por primera vez de manera obligatoria en $13 \%$.

Según los considerandos de la norma, esta modificación obedeció a la necesidad de regularizar los beneficios sociales, indemnizaciones y pensiones de jubilación -que aparentemente se encontraban impagas en la generalidad de los casos-, y asegurar también el futuro el pago del recargo a los trabajadores y su capacitación; destinando estos tres puntos porcentuales adicionales a lo siguiente:

- Un $2 \%$ estaría destinado a regularizar los beneficios sociales, compensaciones por tiempo de servicios y cuotas de jubilación por el recargo cobrado y no pagado por los empleadores en los años anteriores; y,

- El 1\% restante debía ser depositado mensualmente en una cuenta del Banco de la Nación, teniendo como destino lo siguiente:

i) $\quad 1 / 2 \%$ para la creación y mantenimiento del Centro Nacional de Aprendizaje en hoteles y ramos similares; y,

ii) $1 \frac{1}{2} \%$ a la cuenta de la Asociación Peruana de Hoteles, Restaurantes y Afines para asegurar el cumplimiento de la ley que crea el recargo y para becas, capacitación y perfeccionamiento del personal.

Esta norma de regularización no solo mantuvo su naturaleza laboral sino que también creo una especie de contribución en favor del Centro Nacional de Aprendizaje en Hoteles y ramos similares.

\subsubsection{El recargo al consumo regulado por el Decreto Ley $\mathbf{N}^{\circ} 23128(1980$ - 1988)}

En el año 1980, el General Francisco Morales Bermúdez Cerrutti publicó el Decreto Ley $\mathrm{N}^{\circ} 23128$ a través del cual se buscó regular un régimen más equitativo en la distribución del recargo al consumo.

Esta finalidad se desprende de los considerandos del referido decreto ley que reconocía la existencia de un régimen de repartición injusto e inequitativo permitido por las normas predecesoras, vale decir, las Leyes Nros. 14701 y 16658. 
Para lograr esta finalidad, la norma reguló el recargo al consumo en un $10 \%$ de manera obligatoria para una lista de establecimientos y dentro las cuales se incluían ya no solo a los establecimientos de hospedaje y restaurantes, sino también a los casinos de juego, bares, chifas, centros nocturnos, sociales y ramos similares y todas las empresas en general, dedicadas a prestar servicios de alojamiento y/o expendio de comidas y bebidas, efectuado en el establecimiento y fuera de él.

Esta nueva regulación contenía un nuevo mecanismo de distribución obligatoria del recargo al consumo, fijado de la siguiente manera:

i) $10 \%$ entre todos los trabajadores en partes iguales teniendo en consideración los días efectivamente laborados en el mes.

Para el cálculo de los días efectivamente laborados, se consideraban a las vacaciones, inasistencias justificadas por enfermedad, accidentes de trabajo, descanso semanal y aquellas inasistencias que se consideren para el descanso vacacional.

ii) $90 \%$ entre todos los trabajadores de acuerdo a un "sistema de puntaje" establecido por la norma en función a factores de responsabilidad, calificación, especialidad y otros de acuerdo a una "Tabla de Puntaje" anexa a la ley.

Esta tabla de puntajes regulaba puntajes del 1 al 10 y le otorgaba mayor puntaje a los empleados con alto nivel de especialización (chefs, barmans, conserjes, entre otros) y le otorgaba el puntaje mínimo a los cargos ejecutivos (gerentes y directores de área).

Adicionalmente, esta norma regulaba de manera expresa que el monto entregado al trabajador por recargo al consumo no sería considerado como "remuneración" y por tanto, no sería computable para el cálculo de beneficios sociales, ni afecto a indemnización o compensación alguna, ni estaría gravado con el Impuesto a las Remuneraciones, vigente en ese entonces.

En cuando a la oportunidad de pago del recargo, se estableció que el pago al trabajador dentro de los cinco (5) primeros días hábiles del mes siguiente a aquel en el cual se recaude el ingreso bruto. Asimismo, se dispuso la obligación a cargo de la empresa de llevar un libro denominado "10\% de Recargo al Consumo" o "Planilla de 
sistemas mecanizados autorizado por la autoridad de trabajo", en el que se debía llevar el control del monto distribuido mensualmente a los trabajadores.

La norma reguló también que los conflictos derivados de la aplicación del recargo anterior pendientes de resolución ante el Ministerio de Trabajo debían regirse por esta nueva norma y los pactos colectivos existentes debían también adecuarse a ésta.

Por último, esta norma derogó en su integridad la norma de regularización del "recargo" del 10\% aprobado por la Ley $\mathrm{N}^{\circ} 16658$ y derogó también los artículos 1, 2, 3 y 4 de la Ley $\mathrm{N}^{\circ} 14701$, subsistiendo básicamente aquellos que regulaban los derechos y condiciones laborales introducidos por esta última norma.

Esta norma tuvo una vigencia breve de ocho años; no obstante, tal vez fue la que mejor regulación recibió con miras a hacer efectivo el pago del recargo al consumo a los trabajadores.

\subsubsection{El recargo único del $13 \%$ regulado por la Ley $\mathrm{N}^{\circ} 24896(1988$ - 1992)}

En el año 1988, durante el primer gobierno del presidente Alan García Pérez, se publicó la Ley $\mathrm{N}^{\circ} 24896^{3}$, con la cual se introdujo una nueva regulación del recargo al consumo, esta vez bajo la denominación de "recargo único" y con un obligatorio trece por ciento (13\%) aplicable sobre el importe de las facturas que extiendan los establecimientos de hospedaje y/o expendio de bebidas, casinos de juego, bingo, bares, chifas, centros nocturnos, clubes sociales y ramos similares.

Este recargo fue conocido en su época como el "Impuesto al Consumo de Hoteles y Restaurantes", aunque por su naturaleza no constituía estrictamente un impuesto.

El recargo único mantuvo las siguientes características:

- Se regulaba un porcentaje fijo obligatorio del $13 \%$ aplicable sobre el integro de la facturación por todo servicio prestado de alojamiento y consumo incluyendo los servicios afines, tales como lavandería, estacionamiento,

\footnotetext{
${ }^{3}$ El Decreto Ley $N^{\circ} 24896$ - "Establecen un recargo único de 13 por ciento sobre el importe de facturas que extiendan establecimientos de hospedaje y/o expendio de bebidas, casinos de juego, bingo, bares, chifas, centros nocturnos, clubes sociales y ramos similares", fue publicada el 16 de octubre de 1988 y fue derogada mediante el inciso f) del artículo 3 del Decreto Ley $\mathrm{N}^{\circ} 25988$, publicado el 24 de diciembre de 1992.
} 
peluquería, sauna, telefonía, banquetes comerciales, convenciones y cualquier otro prestado.

- $11 \%$ del beneficio debía ser entregado al trabajador reconociéndosele carácter remunerativo y $2 \%$ sería destinado para financiar el pago de la indemnización cancelatoria anual (antecedente de la CTS) y aportaciones de jubilación al IPSS.

- Para su percepción se requería de prestación real y efectiva de servicio, salvo inasistencias justificadas.

- Se excluía del beneficio a los propietarios, accionistas, directores y al gerente.

- Se establecía la obligación de llevar un registro especial autorizado por el Ministerio de Trabajo en donde se registraría en forma quincenal las distribuciones efectuadas.

- Se regulaba la obligación de entregar con carácter de confidencias copias de las facturas emitidas a los representantes de los trabajadores para que estos pudieran llevar un control efectivo de este beneficio.

Esta norma al igual que su predecesora, recogía un mecanismo de distribución de los importes recaudados en función a una denominada "Tabla de Distribución de Porcentajes" de acuerdo a los oficios y ocupaciones del personal.

En su quinto año de vigencia, en el año 1992, esta ley fue derogada de manera expresa por la Ley $\mathrm{N}^{\circ} 25988$, esto en un intento de simplificar el sistema tributario y eliminar privilegios y sobrecostos, entre ellos, el 13\% que se añadía a la facturación en forma obligatoria. Esta ley cambió el panorama existente hasta ese entonces con las características que se detallan a continuación.

\subsection{Consideraciones sobre el actual recargo al consumo (1992 - actualidad)}

\subsubsection{Consideraciones preliminares}

Tal como señalamos en el punto anterior, en el año 1988 mediante la Ley $\mathrm{N}^{\circ} 24896$ se estableció el mal llamado "Impuesto al Consumo de Hoteles y Restaurantes" que tenía 
por beneficiarios a los trabajadores de hospedajes, restaurantes y similares y que consistió en un "recargo único" del 13\% sobre el importe de las facturas que extendieran esa clase de establecimientos. Ese $13 \%$ era distribuido entre los trabajadores según una tabla de puntos prevista en la misma ley, la cual establecía una escala de 10, 8, 6 y 4 puntos en función a las características del servicio prestado por el trabajador.

Con miras a racionalizar el Sistema Tributario y eliminar una serie de sobrecostos y privilegios, es que el 24 de diciembre de 1992 se publicó el Decreto Ley $\mathrm{N}^{\circ}$ 25988, que aprobó la "Ley de Racionalización del Sistema Tributario y de Eliminación de Privilegios y Sobrecostos", que derogó expresamente el "recargo único" previsto en la Ley $\mathrm{N}^{\circ} 24896$.

No obstante lo anterior y con la finalidad de no dejar desprotegidos a esta clase de trabajadores por el cambio repentino del sistema y, en todo caso, dejar a la competencia y el mercado tal sobrecosto, la Quinta Disposición Complementaria de este decreto ley reguló este beneficio bajo la denominación de "recargo al consumo" bajo la siguiente regulación:

QUINTA.- Los establecimientos de hospedaje o expendio de comidas y bebidas en acuerdo con sus trabajadores, podrán fijar un recargo al consumo no mayor al que $13 \%$ del valor de los servicios prestan, en sustitución del tributo que se deroga en el inciso f) del Artículo 3 del presente Decreto Ley. El recargo al consumo, si fuera el caso, será abonado por los usuarios del servicio en la forma y modo que cada establecimiento fije. Su percepción por los trabajadores no tendrá carácter remunerativo y, en consecuencia, no estará afecto a las contribuciones de Seguridad Social ni FONAVI, ni afecto a indemnización, beneficios laborales o compensación alguna. Este recargo no forma parte de la base imponible del Impuesto General a las Ventas.

Con esta nueva regulación, en tanto hubiera acuerdo entre la empresa y los trabajadores, este recargo al consumo podía seguirse distribuyendo entre los trabajadores con características distintas. Por ejemplo, el porcentaje del recargo ya no era obligatorio para todos los restaurantes y hoteles y necesariamente en un monto fijo del $13 \%$, sino hasta un máximo de 13\%, así como también era la ocasión para que, a través del acuerdo entre las partes, se pudiera modificar la forma de determinar los puntos, la oportunidad del pago, entre otras características que se desarrollan a continuación. 


\subsubsection{Características del recargo al consumo}

\subsubsection{Establecimientos facultados a implementar el cobro del recargo al consumo}

Conforme a la norma de creación del recargo al consumo, este puede ser implementado en acuerdo con los trabajadores únicamente en: i) establecimientos de hospedaje; y, ii) establecimientos de expendio de comidas y bebidas.

Nuestra legislación no recoge una definición de establecimientos de expendio de comidas y bebidas; no obstante, debemos entender que en forma general la norma se refiere a restaurantes y bares. En ese sentido, a continuación presentamos definiciones de los establecimientos habilitados para el cobro del recargo al consumo, obtenidas del Reglamento de Establecimientos de Hospedaje, aprobado por Decreto Supremo $\mathrm{N}^{\circ} 029$ 2004-MINCETUR, publicada el 27 de noviembre de 2004, y del Reglamento de Restaurantes, aprobado por Decreto Supremo No 025-2004-MINCETUR, publicada el 10 de noviembre de 2004:

- Establecimiento de hospedaje: lugar destinado a prestar habitualmente servicio de alojamiento no permanente, para que sus huéspedes pernocten en el local, con la posibilidad de incluir otros servicios complementarios, a condición del pago de una contraprestación previamente establecida en las tarifas del establecimiento. (Literal a) del artículo 3 del Reglamento de Establecimientos de Hospedaje, aprobado por Decreto Supremo No 029-2004-MINCETUR.)

- Restaurante: Establecimiento que expende comidas y bebidas al público, preparadas en el mismo local, prestando el servicio en las condiciones que señala el presente Reglamento y de acuerdo a las normas sanitarias correspondientes. (Literal a) del artículo 3 del Reglamento de Restaurantes, aprobado por Decreto Supremo $\mathrm{N}^{\circ}$ 025-2004-MINCETUR.)

- Bar: Recinto del Restaurante, caracterizado por contar con una barra o mostrador, destinado al servicio de bebidas de diversa índole y otros. (Literal c) del artículo 3 del Reglamento de Restaurantes, aprobado por Decreto Supremo № 025-2004MINCETUR.)

\subsubsection{Trabajadores beneficiarios}


A diferencia de la norma anterior que excluía expresamente al gerente de la empresa, la actual regulación del recargo al consumo resulta de aplicación a la generalidad de trabajadores con los que el establecimiento de hospedaje o restaurante mantenga un vínculo laboral e independientemente de la modalidad contractual (contratos sujetos a modalidad, tiempo parcial, entre otros).

En este orden de ideas, no existe la posibilidad que el recargo al consumo sea repartido con personas con las cuales no se mantiene un vínculo laboral, tales como locadores de servicios, directores, practicantes, entre otros.

Nótese que la norma no establece como requisito del beneficio la prestación efectiva de trabajo. Esta falta de regulación determina que el recargo al consumo deba ser pagado independientemente del número de horas trabajadas, descansos vacacionales y ausencias justificadas o no.

\subsubsection{Porcentaje del recargo al consumo}

La regulación anterior establecía un recargo único del trece por ciento (13\%) aplicable sobre el importe de las facturas que extienda todo establecimiento de hospedaje y/o expendio de comidas y bebidas. La regulación actual, faculta a que los trabajadores de común acuerdo con los establecimientos de hospedaje y/o expendio de comidas y bebidas, regulen el porcentaje del recargo al consumo, con un tope máximo del 13\% sobre el valor de los servicios facturados a los consumidores.

\subsubsection{Forma de cálculo del recargo al consumo}

El recargo al consumo es aplicable sobre el valor de los servicios que presten los establecimientos de hospedaje y restaurantes, sin que éste forme parte de la base imponible del Impuesto General a las Ventas (IGV).

Entonces, tanto el IGV como el recargo al consumo comparten la misma base de cálculo, según se presenta a continuación:

$\begin{array}{lllr}\text { Base imponible del IGV por servicios } & = & \mathrm{S} / & 100.00 \\ \mathrm{IGV} \text { de ventas }(18 \%) & = & \mathrm{S} / & 18.00 \\ \text { Recargo al consumo }(13 \%) & = & \mathrm{S} / & 13.00 \\ \text { Precio de Venta } & = & \mathrm{S} / 131.00\end{array}$


Tal como se puede, apreciar el recargo al consumo es de aplicación sobre el valor de los servicios prestados por el establecimiento, sin que dicha base de cálculo se vea incrementada por el valor del IGV para efectos de su cálculo.

Es importante señalar que el recargo al consumo no debe aplicarse en operaciones de venta de bienes, ya que solo es aplicable a servicios prestados en establecimientos de hospedaje y restaurantes.

\subsubsection{Forma de distribución del recargo al consumo}

La forma de distribución de recargo al consumo debe ser determinada por acuerdo entre trabajadores y los establecimientos de hospedaje y restaurantes, sin que la norma regule una forma alternativa de reparto ante la falta de acuerdo.

Es importante recalcar que, la falta de acuerdo respecto de la forma de distribución, de ninguna manera habilita a que los establecimientos de hospedaje y restaurantes establezcan arbitrariamente la forma de distribución e incluso que lo modifiquen en el tiempo de manera unilateral, como efectivamente ocurre en la realidad. La ausencia de acuerdo respecto de la distribución, debería llevar a distribuir el total del recargo al consumo entre el número total de trabajadores.

Es común encontrar en la práctica, casos en los que los establecimientos de hospedaje y restaurantes fijan de manera unilateral el cobro del recargo al consumo, determinado también de manera unilateral la forma de distribución entre los trabajadores, situación que no necesariamente se rige por un principio de equidad. Asimismo, es común encontrar situaciones, en las que los gerentes de los establecimientos o trabajadores que no necesariamente contribuyen con el servicio, se asignan una parte sustancial del recargo al consumo o se varía cada mes la forma de distribución entre los trabajadores dependiendo del monto recaudado en el mes o del ánimo del empleador. Se observan también casos en los que, el empleador varía el monto del recargo de los trabajadores como una especie de sanción patrimonial, disminuyendo el monto del recargo a repartir en función a las tardanzas u horas dejadas de trabajadas, desnaturalizando de esta manera la finalidad del recargo.

La ausencia de acuerdo un expreso en la forma de distribución del recargo al consumo, conlleva que el mismo deba ser distribuido entre todos los trabajadores por 
igual, dividiendo el total del ingreso por este concepto entre el número de trabajadores. Es por esta razón que, cualquier forma de distribución distinta a ésta y que no tenga como fuente el acuerdo de voluntades, puede generar válidamente un reclamo por parte de los trabajadores afectados.

Al respecto, Obregón Sevillano (2005) opina que ante la ausencia de acuerdo, resulta factible que los establecimientos de hospedaje y restaurantes utilicen la tabla de distribución contenida en la norma anterior que regulaba el recargo único (p. V16), opinión con la cual discrepamos puesto que dicha norma se encuentra derogada en todos sus extremos.

\subsubsection{Plazo para el pago del recargo al consumo}

El plazo para el pago del recargo al consumo es también un aspecto que la norma deja a la voluntad de las partes. En la práctica, el recargo al consumo es repartido en función a la periodicidad en el pago de las remuneraciones (semanal, quincenal, mensual), sin embargo, esto no imposibilita que las partes no puedan fijar plazos distintos para el pago.

La falta de regulación en la determinación de la oportunidad del pago, faculta al trabajador a exigir el pago del recargo al consumo de manera inmediata, una vez que los establecimientos de hospedaje y restaurantes hagan cobro del recargo a sus clientes. Este plazo de exigibilidad del pago puede extraerse del artículo 1240 del Código Civil, el cual dispone que si no hubiese plazo designado, el acreedor puede exigir el pago inmediatamente después de contraída la obligación.

No obstante lo antes señalado, resulta evidente que, en la práctica, el trabajador opte por no exigir el pago del recargo al consumo por temor a las consecuencias que ello podría acarrear en virtud a la relación de subordinación que mantiene frente a su empleador, por lo que, en la mayoría de casos, las acciones de cobranza se realizan una vez que se produce la extinción del vínculo laboral.

Esto nos lleva a hacer mención de otro gran inconveniente que se le presenta al trabajador que desea exigir el pago del recargo al consumo, que es el relacionado con el plazo de prescripción para accionar por el pago y la vía a la que debe acudir para lograr dicha finalidad. 
Respecto del plazo de prescripción para exigir al establecimiento de hospedaje o restaurante que cumpla con el pago del recargo al consumo, partiendo de la premisa que se trata de un beneficio económico proveniente de una relación laboral, el plazo de prescripción es el de cuatro años regulado por la Ley $\mathrm{N}^{\circ}$ 27321, Ley que Establece Nuevo Plazo de Prescripción de las Acciones Derivadas de la Relación Laboral y que indica en su artículo único, que este plazo de prescripción se computa desde la fecha de extinción del vínculo laboral.

En cuanto a la vía adecuada para ejercer el cobro por parte de los trabajadores, podemos señalar que la vía procesal adecuada es la del proceso laboral, conforme al artículo 2 de la Ley N ${ }^{\circ}$ 29497. Nueva Ley Procesal de Trabajo. Este aspecto merecerá un mayor desarrollo en el análisis laboral del presente trabajo.

Finalmente, cabe señalar que existen algunos vacíos normativos relacionados al recargo al consumo que también merecerán un análisis posterior, tales como la determinación de la entidad encargada del control en el cumplimiento de la obligación de pago del recargo, mecanismos de registro en el pago y determinación del recargo al consumo que facilite un mecanismo de acceso a la información a los trabajadores, afectación del recargo a los tributos a cargo de trabajadores y empleadores, entre otros.

\subsubsection{El recargo al consumo en el Código de Protección y Defensa del Consumidor}

El Código de Protección y Defensa del Consumidor, aprobado mediante Ley No 29571 publicado 2 de setiembre del 2010, tiene por finalidad que los consumidores accedan a productos y servicios idóneos, y que gocen de los derechos y los mecanismos efectivos para su protección, reduciendo la asimetría informativa, corrigiendo, previniendo o eliminando las conductas y prácticas que afecten sus legítimos intereses.

En concordancia con la finalidad antes señalada, es que dicho código contempla diversas normas para corregir la relación de asimetría informativa que existe entre proveedores y consumidores; $y$, dentro de ellas existe una regulación especial para el recargo al consumo.

Es así que, en el artículo $5^{4}$ del citado Código, se dispone que los establecimientos de hospedaje y restaurantes se encuentran en la obligación de colocar

\footnotetext{
4 “Artículo 5.- Exhibición de precios o de listas de precios
} 
sus listas de precios en el exterior, de forma accesible y visible para consulta del consumidor, encontrándose prohibido el cobro de montos adicionales por cualquier tipo de concepto o recargo de manera disgregada al precio final, con excepción del recargo al consumo, en cuyo caso debe informarse al consumidor de manera oportuna, accesible $\mathrm{y}$ visible.

Debe entenderse que la lógica del Código es que el consumidor sea informado adecuadamente del precio que debe pagar por el servicio y que no se le exija el pago de conceptos adicionales, como el denominado "derecho de cubierto" o "derecho de mantelería", que eran comunes en muchos establecimientos. Por lo tanto, siguiendo la línea de desarrollo del Código, el único concepto adicional que puede cobrarse al consumidor en forma disgregada sería el recargo al consumo.

Finalmente, aunque el Código no establece cómo es que el recargo al consumo debe informarse al consumidor, consideramos que la alternativa más idónea, es que el precio final consignado en los listados de precios ya incluya el recargo al consumo y esto se le informe al consumidor, haciéndose indicación del porcentaje cobrado en el establecimiento por dicho recargo.

5.1 Los establecimientos comerciales están obligados a consignar de manera fácilmente perceptible para el consumidor los precios de los productos en los espacios destinados para su exhibición. Igualmente, deben contar con una lista de precios de fácil acceso a los consumidores. En el caso de los establecimientos que expenden una gran cantidad de productos o servicios, estas listas pueden ser complementadas por terminales de cómputo debidamente organizados y de fácil manejo para los consumidores.

...

5.3 Los establecimientos que expenden comidas y bebidas y los servicios de hospedaje y hostelería están obligados a colocar sus listas de precios en el exterior, de forma accesible y visible para consulta del consumidor. En estos servicios está prohibido el cobro de montos adicionales por cualquier tipo de concepto o recargo de manera disgregada al precio final, con excepción del recargo al consumo por concepto de servicio de los trabajadores previsto en norma especial, en cuyo caso debe informarse al consumidor de manera oportuna, accesible y visible." 


\section{CAPÍTULO II: ASPECTOS LABORALES DEL RECARGO AL CONSUMO}

El presente capitulo tiene por objeto establecer la naturaleza del recargo al consumo y, consecuentemente, determinar si el mismo tiene o no una naturaleza remunerativa. Asimismo, tiene por finalidad establecer la competencia jurisdiccional adecuada en la que se deberán discutir los reclamos de los trabajadores relacionados a la exigibilidad del recargo al consumo.

Para tal efecto, inicialmente haremos un análisis conceptual de la contraprestación que emana por parte del empleador en el desarrollo de una relación laboral para finalmente establecer si el recargo al consumo tiene o no una naturaleza remunerativa.

Por último, en el desarrollo de la segunda parte de este capítulo analizaremos cual es la entidad que tiene a su cargo la labor de fiscalización en el pago del recargo al consumo y la competencia de los juzgados para conocer procesos en los que se discute la exigibilidad en el pago del recargo al consumo.

\subsection{Desarrollo conceptual del recargo al consumo desde el punto de vista laboral}

Por señalamiento expreso de su norma de creación, la percepción del Recargo al Consumo no tiene carácter remunerativo, por lo tanto, no es base de cálculo de aportes provisionales ni para el pago de beneficios sociales.

No obstante lo anterior, merece especial interés el análisis de la naturaleza remunerativa de dicho recargo a la luz de la legislación y jurisprudencia en materia laboral, al existir posiciones contradictorias emitidas por juzgados laborales con relación a la naturaleza remunerativa de dicho recargo.

Es así que, para efectos del presente análisis, seguidamente delimitaremos qué se entiende por remuneraciones, conceptos no remunerativos y condiciones de trabajo para efectos laborales para finalmente delimitar la naturaleza jurídica del recargo.

\subsubsection{Conceptos remunerativos}


Nuestra legislación reconoce a la remuneración, conjuntamente con la prestación personal de servicios y la subordinación, como uno de los elementos esenciales que integra a toda relación laboral al señalar que, en toda prestación personal de servicios remunerados y subordinados, se presume la existencia de un contrato de trabajo a plazo indeterminado (artículo 4 de la Texto Único Ordenado Ley de Productividad y Competitividad Laboral, aprobada por Decreto Supremo No 003-97-TR publicada el (en adelante la LPCL).

Sobre lo que debe entenderse por remuneración, Toyama (2001) es de la siguiente opinión:

La remuneración no solamente es un elemento esencial del contrato de trabajo, sino que constituye un derecho fundamental reconocido por el artículo 24 de la Constitución de 1993. ... Consideramos que la remuneración es todo lo que percibe el trabajador por sus servicios prestados y que representa una ventaja o beneficio patrimonial para el mismo y su familia, sin tener en cuenta la condición, el plazo o la modalidad de entrega, salvo que, ciertamente, se encuentre excluido. (pp. 291-292)

En este mismo sentido, el artículo 6 de la LPCL, dispone que constituye remuneración el íntegro de lo que el trabajador recibe por sus servicios, en dinero o en especie, cualquiera sea la forma o denominación que tenga, siempre que sean de su libre disposición, incluyendo las sumas de dinero que se entreguen directamente al trabajador en calidad de alimentación principal, como desayuno, almuerzo o refrigerio que lo sustituya o cena. Señalando además que, no constituye remuneración para ningún efecto legal el valor de las prestaciones alimentarias otorgadas bajo la modalidad de suministro indirecto.

La remuneración entonces, debe ser entendida como todo beneficio o incremento patrimonial de libre disposición del trabajador y que recibe del empleador (y no de un tercero) como contraprestación directa de los servicios personales brindados a éste.

Tomando en cuenta esta noción de lo que debe entenderse como remuneración, podemos establecer que el recargo al consumo si bien es cierto tiene relación con el servicio prestado por el trabajador, no tiene naturaleza remunerativa toda vez que para el empleador este pago no constituye propiamente una contraprestación por los servicios personales prestados por el trabajador. 
El pago realizado por concepto de recargo al consumo lo realiza el empleador pero por cuenta de los clientes de éste, situación que en nuestra opinión descalifica a dicho concepto como uno de naturaleza remunerativa.

\subsubsection{Conceptos no remunerativos}

Complementando el concepto de remuneración contenido en la LPCL, el artículo 7 de la referida Ley, establece que no constituyen remuneración los conceptos previstos en los artículos 19 y 20 del Texto Único Ordenado de la Ley de Compensación por Tiempo de Servicios, aprobado por el Decreto Supremo N 001-97-TR (en adelante Ley de CTS). Sobre este punto, el artículo $19^{5}$ del Texto Único Ordenado de la Ley de Compensación por Tiempo de Servicios, recoge una lista taxativa de conceptos no remunerativos para efectos de la Compensación por Tiempo de Servicios -y por consiguiente, no son considerados remuneración para todo efecto laboral-, dentro de los cuales se encuentran las gratificaciones extraordinarias, la participación en las utilidades y las condiciones de trabajo, entre otros. Por su parte el artículo 20 de la misma norma

\footnotetext{
${ }^{5}$ Texto Único Ordenado de la Ley de Compensación por Tiempo de Servicios, aprobado por el Decreto Supremo $\mathrm{N}^{\circ}$ 001-97-TR

Artículo 19.- No se consideran remuneraciones computables las siguientes:

a) Gratificaciones extraordinarias $u$ otros pagos que perciba el trabajador ocasionalmente, a título de liberalidad del empleador o que hayan sido materia de convención colectiva, o aceptadas en los procedimientos de conciliación o mediación, o establecidas por resolución de la Autoridad Administrativa de Trabajo, o por laudo arbitral. Se incluye en este concepto a la bonificación por cierre de pliego;

b) Cualquier forma de participación en las utilidades de la empresa;

c) El costo o valor de las condiciones de trabajo;

d) La canasta de Navidad o similares;

e) El valor del transporte, siempre que esté supeditado a la asistencia al centro de trabajo y que razonablemente cubra el respectivo traslado. Se incluye en este concepto el monto fijo que el empleador otorgue por pacto individual o convención colectiva, siempre que cumpla con los requisitos antes mencionados;
}

f) La asignación o bonificación por educación, siempre que sea por un monto razonable y se encuentre debidamente sustentada;

g) Las asignaciones o bonificaciones por cumpleaños, matrimonio, nacimiento de hijos, fallecimiento y aquéllas de semejante naturaleza. Igualmente, las asignaciones que se abonen con motivo de determinadas festividades siempre que sean consecuencia de una negociación colectiva;

h) Los bienes que la empresa otorgue a sus trabajadores, de su propia producción, en cantidad razonable para su consumo directo y de su familia;

i) Todos aquellos montos que se otorgan al trabajador para el cabal desempeño de su labor o con ocasión de sus funciones, tales como movilidad, viáticos, gastos de representación, vestuario y en general todo lo que razonablemente cumpla tal objeto y no constituya beneficio o ventaja patrimonial para el trabajador; j) La alimentación proporcionada directamente por el empleador que tenga la calidad de condición de trabajo por ser indispensable para la prestación de servicios, las prestaciones alimentarias otorgadas bajo la modalidad de suministro indirecto de acuerdo a su ley correspondiente, o cuando se derive de mandato legal. 
excluye de la remuneración computable a la alimentación proporcionada directamente por el empleador que tenga la calidad de condición de trabajo por ser indispensable para la prestación de los servicios, o cuando se derive de un mandato legal.

En concordancia con lo antes señalado, en principio sólo calificarían como conceptos no remunerativos aquellos señalados expresamente en los artículos 19 y 20 de la Ley de CTS; no obstante, existen determinados conceptos que pese a no encontrarse taxativamente señalados en estos artículos, por señalamiento expreso de alguna norma o por su naturaleza no podrían ser considerados como remunerativos, tal es el caso de la compensación por tiempo de servicios, las indemnizaciones previstas por las normas laborales e incluso el propio recargo al consumo que por disposición normativa no constituye un concepto remunerativo.

A partir de los antecedentes del recargo al consumo, podemos inferir que el recargo en buena cuenta se tradujo en la legislación como una internalización a nivel jurídico de las propinas, pero que por encontrarse reguladas a nivel normativo perdieron el carácter de liberalidad y por tanto, pasaron a tener una naturaleza distinta con su inclusión como un beneficio económico regulado por ley que en el caso peruano no tiene actualmente naturaleza remunerativa.

Toyama (2001), citó el caso de Venezuela como uno de los países los que las propinas califican como conceptos remunerativos, al señalar lo siguiente:

Pese a lo dicho, en países como Venezuela, las propinas califican como remuneraciones. Así, el artículo 134 de la Ley Orgánica de Trabajo anota que en los locales en que se acostumbre cobrar al cliente por el servicio un porcentaje sobre el consumo, tal recargo se computará en el salario, en la proporción que corresponda a cada trabajador de acuerdo con lo pactado, la costumbre o el uso (p. 295).

Expuesto lo anterior, seguidamente analizaremos si el recargo al consumo califica como condición de trabajo o como algún concepto no remunerativo.

\subsubsection{Las condiciones de trabajo}

El literal c) del referido artículo 19 de la LPCL, establece que no son considerados con carácter de remuneración el valor de las condiciones de trabajo. Como su nombre lo dice, una condición de trabajo es toda aquella condición de carácter indispensable para que el trabajador pueda realizar sus labores. Es decir, no basta con que sea un aspecto 
relacionado a la prestación del servicio sino que, debe consistir en una condición sin la cual no sería posible para el trabajador ejecutar su labor.

Un ejemplo característico de condición de trabajo, se encuentra representado por la entrega de herramientas y uniformes de trabajo que son estrictamente necesarios para la ejecución del servicio encomendado por el empleador.

Adicionalmente, las condiciones de trabajo tienen la característica de no constituir una ventaja patrimonial para el trabajador, ni ser de su libre disposición.

En el caso materia de nuestro análisis, pese a que el recargo al consumo si representa una ventaja patrimonial para el trabajador, este no podría ser considerado como una condición de trabajo al no ser su entrega indispensable para la prestación del servicio.

Por consiguiente, se concluye que los pagos efectuados por concepto de recargo realizados por los establecimientos de hospedaje y restaurantes por cuenta de sus clientes a favor de sus trabajadores no constituyen una condición de trabajo y, en consecuencia, no constituyen remuneración para efectos laborales.

\subsubsection{Otros conceptos no remunerativos}

Conforme a su ley de creación, el recargo al consumo no tiene una naturaleza remunerativa, sin embargo, el análisis de la naturaleza de este concepto va más allá de lo expresamente señalado por la norma. En efecto, además de la disposición legal expresa, existen algunas resoluciones emitidas por los juzgados laborales en los que se discute la naturaleza de este concepto que se origina en una relación de índole laboral.

El recargo al consumo, si bien es cierto es pagado por el empleador, los fondos para el pago de dicho recargo provienen de los clientes de los establecimientos de hospedaje y restaurantes. Esta situación determina que la entrega de dicho concepto no constituya realmente una contraprestación directa por los servicios personales brindados al empleador.

En este mismo sentido, se pronunció la Sentencia recaída en el Expediente $\mathrm{N}^{\circ}$ 5523-94 BS, del 4 de abril de 1995, que en su segundo considerando señala lo siguiente:

Se excluye como parte de la remuneración computable el porcentaje de consumo, no teniendo este concepto carácter remunerativo, siendo de naturaleza variable de acuerdo 
a los ingresos percibidos por el consumo, costo que no es asumido por el empleador al amparo de la Quinta Disposición Complementaria del Decreto Ley N 25988.

Es de apreciarse que un elemento esencial para determinar si el recargo al consumo tiene o no naturaleza remunerativa encuentra determinado por el sujeto que finalmente soporta la carga económica de dicho pago.

En el caso materia de análisis, los establecimientos de hospedaje y restaurantes no soportan a carga económica de dicho pago sino que actúan como agentes de percepción del recargo, recibiendo este monto de sus clientes y trasladándolo a sus trabajadores, razón por la cual consideramos que no tiene el carácter remunerativo.

Sobre la naturaleza remunerativa del recargo al consumo, Benavides Mancilla (2012) considera que:

Constituye remuneración para todo efecto legal, el íntegro de lo que el trabajador recibe por sus servicios (retribución a su trabajo), en dinero o en especie, sin interesar la forma o la denominación, siempre que sea de su libre disposición.

Temiendo en cuenta este supuesto, podemos ver que el recargo al consumo cumple las condiciones establecidas en la ley laboral y por lo tanto tiene un carácter remunerativo que daría lugar a que este importe, tenga que estar gravado con el Impuesto a la Renta. (p.6)

Discrepamos con la opinión anterior, puesto que el considerar a una entrega de dinero como de libre disposición no convierte a dicha entrega en remuneración (esto podría ocurrir con el caso de las propinas por ejemplo), ya que quedaría pendiente analizar si dicha entrega proviene de un tercero distinto al empleador (como ocurre en el caso de las propinas y el recargo al consumo) y si existe una exclusión normativa de dicho concepto como remunerativo (como ocurre en el caso del recargo al consumo).

Considerar equivocadamente al recargo al consumo como remunerativo, en la práctica traería una serie de consecuencias negativas para las empresas. Esto se explica en el hecho que, la remuneración de los trabajadores de establecimientos de hospedaje y restaurantes se convertirían en remuneraciones variables ya que mensualmente tendrían que calcular la remuneración a pagar que integre el recargo, situación que además de incrementar los costos laborales, generaría una situación de incertidumbre jurídica al momento de contratar, toda vez que, el empleador no tendría como establecer cuánto es lo que efectivamente pagará al trabajador, al existir en la remuneración un componente indeterminado en ese momento, en este caso el "recargo al consumo". 


\subsection{Naturaleza jurídica del recargo al consumo}

Cuando hablamos del recargo al consumo estamos frente a una obligación que tiene como fuente en primer lugar a la ley que prevé el cobro del recargo al consumo y en segundo lugar a la autonomía de la voluntad existente entre los establecimientos de hospedaje o expendio de comidas y bebidas y sus trabajadores, quienes de común acuerdo fijan el cobro del recargo al consumo y demás aspectos esenciales tales como la forma de reparto, oportunidad de pago, entre otros.

Ahora bien, esta obligación se genera en el marco de la relación laboral existente entre el establecimiento de hospedaje o de expendio de comidas y bebidas, y el trabajador, y que por lo tanto es un beneficio económico de naturaleza laboral, pero que no posee la naturaleza de un concepto remunerativo.

Así ha sido reconocido en la jurisprudencia nacional, tal como puede desprenderse de la Sentencia recaída en el Expediente N²204-2001 BE (A-S), del 23 de julio de 2001, que en su segundo considerando señala lo siguiente:

SEGUNDO: que, de conformidad con el literal d) del inciso segundo del artículo cuarto de la Ley Procesal de Trabajo $\mathrm{N}^{\circ} 26636$, los juzgados de trabajo conocen de las pretensiones individuales por conflictos jurídicos sobre pago de remuneraciones y beneficios económicos, y en este último concepto se comprende el recargo al consumo que los establecimientos de hospedaje o expendio de comidas y bebidas, acuerden con sus trabajadores conforme prevé la Quinta Disposición Complementaria del Decreto Ley $\mathrm{N}^{\circ} 25988$, ya que su percepción posterior por éstos es consecuencia precisamente de su condición de tales, siendo infundada por tal razón la excepción de incompetencia propuesta por la demandada ...

En este orden de ideas, el recargo al consumo tiene la naturaleza de un beneficio económico no remunerativo determinado por ley y que es pagado por los establecimientos de hospedaje y restaurantes a sus trabajadores y por cuenta de los clientes de dichos establecimientos.

Nótese que, la carga económica del recargo al consumo es soportada por los clientes de los establecimientos de hospedaje y restaurantes, quienes ven incrementada la retribución a pagar por los servicios consumidos -por efecto del recargo- con la finalidad de atender al pago del recargo al consumo para los trabajadores. 
Finalmente, debemos señalar que el considerar que el recargo al consumo tiene una naturaleza laboral -ciertamente lo tuvo desde sus orígenes- conlleva que, los aspectos relacionados a su exigibilidad, aplicación de intereses, plazo de prescripción, entre otros, deben ser regulados por las normas laborales.

\subsection{Fiscalización administrativa}

Otro aspecto que se deriva también del carácter laboral que posee el recargo al consumo, es su inclusión como uno de los conceptos que debe estar sujeto a fiscalización por parte de la Autoridad Administrativa de Trabajo.

En ese orden de ideas, debemos tener en cuenta lo señalado por el artículo $3^{6} \mathrm{de}$ la Ley $\mathrm{N}^{\circ}$ 28806, que aprueba la Ley General de Inspección del Trabajo y que incluye en el marco de las funciones de la inspección de trabajo, la vigilancia y exigencia del cumplimiento de las normas legales reglamentarias, convencionales y condiciones contractuales en el orden sociolaboral, sea cual fuere el régimen laboral.

Y siguiendo esa línea, la Ley $N^{\circ} 29881$ le asigna la facultad de ejercer la inspección laboral a la Superintendencia Nacional de Fiscalización Laboral (SUNAFIL), de forma tal que, es ésta la entidad la competente para ejercer la fiscalización del cumplimiento del pago del recargo al consumo a favor de los trabajadores de los establecimientos de hospedaje y de expendio de alimentos y bebidas.

Entonces, resulta ser la SUNAFIL la autoridad administrativa encargada de velar por el cumplimiento de las obligaciones relacionadas al recargo al consumo, teniendo esta además de la facultad de sancionar administrativamente la inobservancia de las obligaciones de pago del recargo al consumo.

En la práctica, las acciones de fiscalización por parte de la autoridad laboral sobre el pago del recargo al consumo son inexistentes, situación nos hace reflexionar

\footnotetext{
6 “Artículo 3.- Funciones de la Inspección del Trabajo

Corresponde a la Inspección de Trabajo el ejercicio de la función de inspección y de aquellas otras competencias que le encomiende el Ordenamiento Juridico Sociolaboral, cuyo ejercicio no podrá limitar el efectivo cumplimiento de la función de inspección, ni perjudicar la autoridad e imparcialidad de los inspectores de trabajo.

Las finalidades de la inspección son las siguientes:

1. De vigilancia y exigencia del cumplimiento de las normas legales, reglamentarias, convencionales y condiciones contractuales, en el orden sociolaboral, ya se refieran al régimen de común aplicación o a los regímenes especiales ..."
} 
sobre la necesidad de que dicha autoridad realice campañas informativas y de verificación en el pago del recargo al consumo.

\subsection{Competencia jurisdiccional de los juzgados laborales en materia del recargo al consumo}

Aun cuando señalemos y afirmemos que el recargo al consumo es un beneficio económico de carácter laboral no remunerativo, y se hubiere pactado con el empleador su percepción sobre el precio de venta para trasladarlo al cliente en beneficio del trabajador, el incumplimiento de la distribución es pasible de reclamo en la vía judicial laboral.

En efecto, siendo el recargo al consumo un beneficio económico originado en una relación laboral, resulta comprendido dentro de los conceptos que pueden ser reclamados en la vía judicial laboral. Así lo podemos desprender del Artículo II $^{7}$ del Título Preliminar de la Nueva Ley Procesal del Trabajo.

Claramente, la pretensión de pago del recargo al consumo debe ser encauzada en la vía judicial laboral, por ser una obligación originada en la prestación de servicios personales bajo subordinación del trabajador frente al empleador, que en este caso es un establecimiento de hospedaje o de expendio de alimentos y bebidas.

La posibilidad de tramitar reclamos por falta de pago del recargo al consumo en la vía judicial laboral, opera por el solo hecho de ser el empleador el encargado de distribuir el recargo aun cuando éste no soporte efectivamente la carga económica de dicho pago.

\footnotetext{
7 “Artículo II.- Ámbito de la justicia laboral

Corresponde a la justicia laboral resolver los conflictos jurídicos que se originan con ocasión de las prestaciones de servicio de carácter personal, de naturaleza laboral, formativa, cooperativista o administrativa; están excluidas las prestaciones de servicios de carácter civil, salvo que la demanda se sustente en el encubrimiento de relaciones de trabajo. Tales conflictos jurídicos pueden ser individuales, plurales o colectivos, y estar referidos a aspectos sustanciales o conexos, incluso previos o posteriores a la prestación efectiva de los servicios."
} 


\section{CAPÍTULO III: ASPECTOS IMPOSITIVOS DEL RECARGO AL CONSUMO}

\subsection{Aspectos impositivos del recargo al consumo para los trabajadores}

\subsubsection{Recargo al consumo e impuesto a la renta de quinta categoría}

\subsubsection{Sobre la afectación del recargo al consumo al impuesto a la renta de quinta categoría}

Dentro de la problemática relacionada al recargo al consumo podemos distinguir, una primera relacionada con la afectación de éste al impuesto a la renta de quinta categoría y otra relacionada con la forma de pago del Impuesto a la Renta de quinta categoría que como veremos más adelante se encuentra a cargo del propio trabajador.

Sobre la afectación del recargo al consumo al Impuesto a la Renta de quinta categoría, el literal a) del artículo 34 de la Ley del Impuesto a la Renta califica como rentas de quinta categoría a la contraprestación obtenidas por el trabajo personal prestado en relación de dependencia, incluidos cargos públicos, electivos o no, como sueldos, salarios, asignaciones, emolumentos, primas, dietas, gratificaciones, bonificaciones, aguinaldos, comisiones, compensaciones en dinero o en especie, gastos de representación y, en general, toda retribución por servicios personales.

En concordancia con lo anterior, el artículo 57 de la ley antes citada dispone que las rentas de quinta categoría se imputan al ejercicio gravable en que se perciben ${ }^{8}$. En este mismo sentido, el artículo 59 de la misma ley dispone que las rentas se consideran percibidas cuando se encuentren a disposición del beneficiario, aun cuando éste no las haya cobrado en efectivo o en especie.

Como podemos apreciar, el concepto de renta gravada de quinta categoría no necesariamente tiene correspondencia con el concepto de remuneración contenido en las

\footnotetext{
${ }^{8}$ De acuerdo al criterio de lo percibido, un ingreso se encontrará sujeto al impuesto una vez que éste es puesto a disposición del beneficiario, entendiéndose por puesta a disposición a la fecha en la que el contribuyente puede hacer suyo el ingreso, dependiendo solo de su voluntad que tal situación acontezca. Este criterio es recogido en la RTF $N^{\circ}$ 05657-5-2004 del 11 de agosto de 2004.
} 
normas laborales, al ser el primero un concepto de mayor amplitud y que parte de la premisa que el ingreso percibido se encuentra gravado en tanto tenga su origen en el trabajo personal, salvo que dicho ingreso califique como rentas no gravadas contenidas en la propia ley ${ }^{9}$.

El ingreso que percibe el trabajador por concepto del recargo al consumo no tiene naturaleza remunerativa no sólo por señalamiento expreso de la norma que crea el recargo al consumo sino también porque el mismo no constituye una contraprestación directamente relacionada con la existencia de la relación laboral.

Por su parte, teniendo en consideración que la entrega del recargo al consumo representa un ingreso derivado indirectamente de la existencia de una relación laboral y aun cuando no sea pagado por el empleador, podemos afirmar que si constituye renta de quinta categoría. Esta afirmación se sustenta en el hecho que el recargo constituye una contraprestación pagada por los servicios personales brindados en los establecimientos de hospedaje y hoteles, independientemente que el mismo sea pagado por los clientes de dichos establecimientos.

Entonces, resulta innegable que el recargo al consumo se encuentra afecto al Impuesto a la Renta de quinta categoría aun cuando el origen de dicho ingreso no provenga directamente del propio empleador sino de los clientes de éste al constituir un ingreso producto del trabajo personal. Esta posición es compartida por el Tribunal Fiscal, quien a través de la Resolución $\mathrm{N}^{\circ}$ 03669-3-2015 del 14 de abril de 2015, concluyo lo siguiente:

... Para efectos del Impuesto a la Renta, se considera como renta de quinta categoría toda retribución que obtiene el trabajador por sus servicios personales, dado que se pretende gravar la totalidad de los ingresos de aquél, razón por la que las sumas que éste percibe por concepto de "recargo al consumo" (regulado por la Quinta Disposición Complementaria del D.L. $\mathrm{N}^{\circ} 25988$ ) califican como renta de quinta categoría.

\footnotetext{
9 Dentro de las rentas no gravadas, en primer lugar, identificamos a las "rentas inafectas" reguladas expresamente en el artículo 18 de la Ley del Impuesto a la Renta y dentro de las cuales destacan las indemnizaciones previstas por leyes laborales, la CTS, los subsidios, entre otros. En segundo lugar, encontramos como rentas no gravadas a las "condiciones de trabajo" a que hace referencia el literal a) del artículo 34 de la ley y que excluye del impuesto a las cantidades que percibe el trabajador por asuntos del servicio en lugar distinto al de su residencia habitual, tales como gastos de viaje, viáticos por gastos de alimentación y hospedaje, gastos de movilidad y otros gastos exigidos por la naturaleza de sus labores, siempre que no constituyan sumas que por su monto revelen el propósito de evadir el impuesto. Por último y por señalamiento expreso del literal 1l) del artículo 37 de la Ley del Impuesto a la Renta, no se encontrarán sujetos al impuesto a la renta los "gastos culturales y educativos" recibidos por el personal de la empresa y los destinados a prestar "asistencia en salud" de los trabajadores.
} 
Habiendo establecido que el recargo al consumo se encuentra dentro del ámbito de aplicación del Impuesto a la Renta de quinta categoría, queda por determinar si dicha renta debe tributar vía retención -que deberá efectuar la empresa que paga el recargo al consumo a sus trabajadores por cuenta de sus clientes- o si el trabajador debe liquidar y realizar directamente el pago de dicho impuesto.

\subsubsection{Sobre la forma de pago del impuesto a la renta de quinta categoría}

Respecto de este tema, el Tribunal Fiscal a través de la Resolución № 03669-3-2015 anteriormente citada, precisa que no existe la obligación de retener el Impuesto a la Renta de quinta categoría por parte de los establecimientos de hospedaje y hoteles al no ser éstos los que pagan dicha renta al trabajador sino que trasladan directamente de sus clientes.

Sobre el particular, la resolución recogió expresamente el siguiente criterio:

respecto a la retención del Impuesto a la Renta sobre el recargo al consumo cabe indicar que conforme lo ha señalado la Quinta Disposición Complementaria del Decreto Ley $\mathrm{N}^{\circ} 25988$ dicha suma no tiene carácter remunerativo, toda vez que es abonada por el usuario del servicio y no por el empleador, el cual solo lo traslada a sus trabajadores, y teniendo en cuenta que según lo dispuesto por los artículos $71^{\circ}$ y $75^{\circ}$ de la Ley del Impuesto a la Renta, el empleador es agente de retención respecto de las rentas de quinta categoría sobre las remuneraciones que abone a sus servidores, se concluye que no se ha previsto legalmente la obligación del empleador de retener el impuesto sobre el monto del recargo al consumo al no tener este último carácter remunerativo.

No obstante lo anterior, en la propia resolución $N^{\circ}$ 03669-3-2015 el vocal Sarmiento Díaz hace constar su voto discrepante al señalar que los artículos 71 y 75 de la Ley del Impuesto a la Renta establecen que son agentes de retención quienes paguen o acrediten rentas de quinta categoría y en ese sentido, la empresa se encontraba en la condición y obligación de facilitar el ingreso del tributo al fisco.

El voto discordante del vocal Sarmiento Díaz señaló de manera expresa lo siguiente:

En el presente caso se aprecia que el monto de recargo al consumo fue abonado por el usuario del servicio, sin embargo, su importe fue cobrado por la recurrente, quien acreditó posteriormente al trabajador dicho concepto, por lo que -de conformidad con los artículo $71^{\circ}$ y $75^{\circ}$ de la Ley del Impuesto a la Renta que establecen que son agentes 
de retención quienes paguen o acrediten rentas de quinta categoría, los que deben retener mensualmente sobre las remuneraciones que abonen a sus servidores- la recurrente se encontraba en condición y obligación de facilitar el ingreso del tributo al fisco conforme con las normas de retención del Impuesto a la Renta.

En tal sentido, queda acreditado que el trabajador, en su calidad de perceptor del recargo al consumo, se encontraba obligado al pago del Impuesto a la Renta de Quinta Categoría establecido por la referida norma, correspondiendo a la recurrente efectuar la retención expresamente atribuida por ley, conforme con el criterio señalado en la Resolución del Tribunal Fiscal No 213-3-2000 ${ }^{10}$.

Expuesto lo anterior, consideramos que la posición adoptada por el Tribunal Fiscal consistente en que "el empleador es agente de retención respecto de las rentas de quinta categoría sobre las remuneraciones que abone a sus servidores" no es correcta al ser producto de una interpretación literal y sesgada de la norma. En este sentido, concordamos con la posición contenida en el voto discrepante del vocal Sarmiento Díaz, pero por consideraciones que se exponen a continuación:

- El artículo $71^{11}$ de la Ley del Impuesto a la Renta señala que son agentes de retención de este impuesto las personas que paguen o acrediten rentas consideradas de quinta categoría. Por su parte, el artículo $75^{12}$ de la ley antes mencionada dispone que las personas naturales y jurídicas o entidades públicas o privadas que paguen rentas comprendidas en la quinta categoría,

\footnotetext{
${ }^{10}$ Con relación a los agentes de retención, esta resolución señala expresamente lo siguiente: “Que, si bien es cierto la figura del agente de retención existe porque el legislador ha optado por ella para facilitar el ingreso del tributo al fisco, también lo es que la obligación de la retención se verifica en la medida que el contribuyente se encuentre obligado al pago del tributo establecido claramente en la ley".
}

11 “Artículo 71.- Son agentes de retención:

a) Las personas que paguen o acrediten rentas consideradas de:

i) Segunda categoría; y,

ii) Quinta categoría...."

12 “Artículo 75.- Las personas naturales y jurídicas o entidades públicas o privadas que paguen rentas comprendidas en la quinta categoría, deberán retener mensualmente sobre las remuneraciones que abonen a sus servidores un dozavo del impuesto que, conforme a las normas de esta Ley, les corresponda tributar sobre el total de las remuneraciones gravadas a percibir en el año, dicho total se disminuirá en el importe de las deducciones previstas por el Artículo 46 de esta ley.

Tratándose de personas que presten servicios para más de un empleador, la retención la efectuará aquél que abone mayor renta de acuerdo al procedimiento que fije el reglamento.

Esta retención deberá abonarse al Fisco dentro de los plazos previstos por el Código Tributario para las obligaciones de periodicidad mensual." 
deberán retener mensualmente sobre las remuneraciones que abonen a sus servidores un dozavo del impuesto que, conforme a las normas de esta ley, les corresponda tributar sobre el total de las remuneraciones gravadas a percibir en el año, dicho total se disminuirá en el importe de las deducciones previstas por la misma ley y dentro de los plazos previstos por el Código Tributario para las obligaciones de periodicidad mensual.

- Conforme a las normas antes citadas y haciendo una interpretación sistemática de ambos artículos, la obligación de retener es de aplicación sobre las rentas de quinta categoría pagadas o acreditadas por los sujetos pagadores de dichas rentas e independientemente que lo pagado constituya o no remuneración, bastando para ello que la renta pagada califique como renta de quinta categoría.

- Cuando el artículo 75 de la ley se refiere a remuneraciones que abonen a sus servidores, no debemos entender que se refiere a remuneraciones en términos laborales ya que como hemos visto anteriormente el concepto de renta de quinta categoría es un concepto más amplio y que incluye al de "remuneración" pero no lo limita a éste último. El hecho de aceptar la interpretación del Tribunal Fiscal como válida, nos podría llevar a concluir de manera equivocada que en los casos de las denominadas "rentas de cuarta - quinta" comprendidas en el inciso e) del artículo 34 de la Ley del Impuesto a la Renta ${ }^{13}$, el agente de retención tampoco estaría facultado a efectuar retenciones ya que éste no paga propiamente "remuneraciones" al locador de servicios con el cual mantiene un contrato de naturaleza civil; situación que deviene en un absurdo.

Entonces, cuando los establecimientos de hospedaje y restaurantes realizan el pago del recargo al consumo a sus trabajadores por cuenta de los usuarios, esto no implica de ninguna manera que no se deba proceder a la retención por el hecho que el recargo no

\footnotetext{
${ }^{13}$ Artículo 34.- Son rentas de quinta categoría las obtenidas por concepto de:

$\cdots$

e) Los ingresos obtenidos por el trabajo prestado en forma independiente con contratos de prestación de servicios normados por la legislación civil", cuando el servicio sea prestado en el lugar y horario designado por quien lo requiere y cuando el usuario proporcione los elementos de trabajo y asuma los gastos que la prestación del servicio demanda ..."
} 
califique como "remuneración", puesto que lo que hace el agente de retención es pagar "rentas de quinta categoría", presupuesto de hecho necesario para que la empresa cumpla con su obligación de retener y pagar el tributo al fisco.

Pese a que no es una resolución de observancia obligatoria ${ }^{14}$, el criterio adoptado por el Tribunal Fiscal a través de esta resolución, en la práctica origina una serie de inconvenientes para los perceptores de estas rentas de quinta categoría quienes tendrían que directamente determinar la renta de quinta categoría del ejercicio acumulando sus rentas percibidas en establecimiento de hospedaje o restaurante con el recargo al consumo y pagarla directamente, cuando en la práctica no existe regulación sobre la forma de declaración, determinación y pago $^{15}$ para casos en los que al agente de retención soló está facultado a retener el impuesto sobre la parte de las rentas de quinta categoría que le abona al contribuyente, distintas al recargo al consumo.

\subsubsection{Recargo al consumo y aportaciones sociales}

A diferencia del Impuesto a la Renta de quina categoría que resulta de aplicación sobre todo aquello que la norma tributaria entiende por renta de quinta categoría, en el caso de

${ }^{14}$ Conforme al Texto Único Ordenado del Código Tributario, aprobado por Decreto Supremo No 133 2013-EF, publicado: 22-06-2013 se entiende por Jurisprudencia de Observancia Obligatoria:

Artículo 154.- JURISPRUDENCIA DE OBSERVANCIA OBLIGATORIA

Las resoluciones del Tribunal Fiscal que interpreten de modo expreso y con carácter general el sentido de normas tributarias, las emitidas en virtud del Artículo 102, así como las emitidas en virtud a un criterio recurrente de las Salas Especializadas, constituirán jurisprudencia de observancia obligatoria para los órganos de la Administración Tributaria, mientras dicha interpretación no sea modificada por el mismo Tribunal, por vía reglamentaria o por Ley. En este caso, en la resolución correspondiente el Tribunal Fiscal señalará que constituye jurisprudencia de observancia obligatoria y dispondrá la publicación de su texto en el Diario Oficial.

De presentarse nuevos casos o resoluciones con fallos contradictorios entre sí, el Presidente del Tribunal deberá someter a debate en Sala Plena para decidir el criterio que deba prevalecer, constituyendo éste precedente de observancia obligatoria en las posteriores resoluciones emitidas por el Tribunal.

La resolución a que hace referencia el párrafo anterior así como las que impliquen un cambio de criterio, deberán ser publicadas en el Diario Oficial.

En los casos de resoluciones que establezcan jurisprudencia obligatoria, la Administración Tributaria no podrá interponer demanda contencioso-administrativa."

${ }^{15}$ En la Resolución de Superintendencia N 036-98-SUNAT, publicada el 21 de marzo de 1998, se regula el procedimiento para que contribuyentes de rentas de quinta categoría efectúen pago del impuesto no retenido pero para supuestos distintos a los ocurridos con el recargo al consumo en los cuales: i) el agente de retención por un error en el cálculo de la renta de quinta no hubiera efectuado las retenciones del impuesto, ii) los montos retenidos por éste resultaran inferiores al impuesto que en definitiva le corresponda pagar al contribuyente, o iii) no se hubieran aplicado retenciones por percibir rentas de quinta categoría de una entidad no obligada a efectuar retenciones. 
las aportaciones sociales de ESSALUD y ONP estas resultan de aplicación sobre el concepto de remuneración regulado en nuestra regulación laboral.

Tratándose de las aportaciones a ESSALUD, conforme al literal a) del artículo 6 de la Ley de Modernización de la Seguridad Social en Salud, aprobada por Ley $\mathrm{N}^{\circ}$ 26790 del 17 de mayo de 1997, los aportes por afiliación al ESSALUD son de carácter mensual, y el aporte de los trabajadores en actividad, incluyendo tanto los que laboran bajo relación de dependencia como los socios de cooperativas, equivale al $9 \%$ de la "remuneración", no debiendo ser la base imponible mínima mensual inferior a la Remuneración Mínima Vital vigente. Agrega dicho literal que, para efectos de la determinación de la base imponible, se considera remuneración la así definida por los Decretos Legislativos Nros. 728 y 650 y sus normas modificatorias.

Sobre el particular, el artículo 6 del Decreto Legislativo $\mathrm{N}^{\circ} 728$ que aprobó la Ley de Fomento del Empleo ${ }^{16}$, dispone que constituye "remuneración" para todo efecto legal el íntegro de lo que el trabajador recibe por sus servicios, en dinero o en especie, cualquiera sea la forma o denominación que tenga, siempre que sea de su libre disposición. Por su parte, el artículo $9^{\circ}$ del Decreto Legislativo $\mathrm{N}^{\circ} 650^{17}$ que aprueba la Ley de Compensación por Tiempo de Servicios, señala que constituye "remuneración computable" la remuneración básica y todas las cantidades que regularmente perciba el trabajador, en dinero o en especie como contraprestación de su labor, cualquiera sea la denominación que se les dé, siempre que sean de su libre disposición.

En cuanto a la aportación a la ONP, el artículo 11 de la Ley del Sistema Nacional de Pensiones de la Seguridad Social, aprobada por Decreto Ley $N^{\circ} 19990$, dispone que los empleadores y las empresas de propiedad social, cooperativas o similares, están obligados a retener las aportaciones de los trabajadores asegurados obligatorios en el momento del pago de sus remuneraciones ${ }^{18}$. Para tal efecto, el artículo 8 de la citada norma señala que para los fines del Sistema se considera "remuneración

\footnotetext{
${ }^{16}$ En la actualidad se encuentra vigente el Texto Único Ordenado del D. Leg. $\mathrm{N}^{\circ} 728$, Ley de Productividad y Competitividad Laboral, aprobado por Decreto Supremo N $003-97-T R$, publicado el 27 de marzo de 1997.

${ }^{17}$ El Texto Único Ordenado de esta norma fue aprobado por el Decreto Supremo No 001-97-TR , publicado el 1 de marzo de 1997.

${ }^{18}$ La Segunda Disposición Transitoria de la Ley $N^{\circ}$ 26504, dispone que a partir del 1 de enero de 1997 las aportaciones al Sistema Nacional de Pensiones a que se refiere el Decreto Ley $N^{\circ} 19990$ no deberán ser menores al $13 \%$ de la remuneración asegurable.
} 
asegurable" el total de las cantidades percibidas por el asegurado por los servicios que presta a su empleador o empresa, cualquiera sea la denominación que se les dé, con las excepciones contenidas en el artículo 9 de la ley antes citada, tales como: gratificaciones extraordinarios, participación en las utilidades, condiciones de trabajo, entre otras.

Expuesto lo anterior y en concordancia con lo establecido por la propia norma que regula el recargo al consumo, podemos establecer que tanto la base imponible de las aportaciones a ESSALUD como la de la ONP se encuentran determinadas por lo que nuestras normas laborales entienden por "remuneración”, razón por la cual se concluye que el recargo al consumo al constituir un concepto no remunerativo no deberá formar parte de la base imponible de las aportaciones.

\subsection{Aspectos impositivos para los establecimientos de hospedaje y restaurantes}

\subsubsection{Recargo al consumo e impuesto a la renta empresarial}

\subsubsection{Afectación del recargo al consumo al impuesto a la renta empresarial}

Habiendo establecido previamente la naturaleza del recargo al consumo y determinado que éste no constituye propiamente un ingreso para el establecimiento de hospedaje o restaurante -que en la práctica actúa como un agente de percepción de dicho recargo-, se desprende que la percepción del recargo por parte de los establecimientos de hospedaje y restaurantes no se encuentran sujetos al Impuesto a la Renta empresarial.

La afirmación anterior, se sustenta en los argumentos y consideraciones siguientes: el artículo 1 del Texto Único Ordenado de la Ley del Impuesto a la Renta, aprobado por el Decreto Supremo No 179-2004-EF (en adelante la "Ley del Impuesto a la Renta”), incluye dentro del ámbito de aplicación del impuesto a:

a) Las rentas que provengan del capital, del trabajo y de la aplicación conjunta de ambos factores, entendiéndose como tales aquellas que provengan de una fuente durable y susceptible de generar ingresos periódicos.

b) Las ganancias de capital.

c) Otros ingresos que provengan de terceros, establecidos por la Ley del Impuesto a la Renta. 
d) Las rentas imputadas, incluyendo las de goce o disfrute, establecidas por Ley del Impuesto a la Renta.

El artículo anterior regula las teorías del Impuesto a la Renta que explican si un ingreso se encuentra sujeto a dicho impuesto, por lo que resulta relevante analizar cada una de estas teorías.

De acuerdo con la teoría de la "Renta - Producto" se entiende por renta a la utilidad obtenida de una fuente durable y susceptible de generar ingresos periódicos, de tal manera que los ingresos eventuales no quedarán comprendidos dentro del campo del impuesto.

Villegas (2003), con relación con la teoría de la Renta - Producto señala:

Los conceptos "capital" y "renta" se encuentran estrechamente interconectados toda vez que, la "renta" es el producto neto y periódico que se extrae de una fuente capaz de producirlo y reproducirlo, siendo tal fuente el "capital", y como permanece inalterado pese a producir tal producto, tiene la propiedad de ser una fuente productiva y durable. (p. 395)

Esta teoría se encuentra recogida en el literal a) del artículo 1 de la Ley del Impuesto a la Renta al incluir dentro del ámbito de aplicación del impuesto a las rentas que provengan del capital, del trabajo y de la aplicación conjunta de ambos factores, entendiéndose como tales a aquellas que provengan de una fuente durable y susceptible de generar ingresos periódicos.

Por su parte, el literal b) del artículo 1 de la Ley recoge la teoría del "Flujo de Riqueza”, según la cual se grava todo beneficio económico o utilidad, con independencia que la misma provenga de una fuente periódica o durable. Para esta teoría, la renta se encuentra representada por la totalidad de enriquecimientos que desde terceros fluyen hacia el contribuyente en un período determinado.

La Ley recoge también en el literal d) del artículo 1 como renta gravada a las "rentas imputadas", entendidas estas como un reconocimiento presunto de un ingreso que no es percibido efectivamente pero que es reconocido como tal por señalamiento expreso de la ley. En efecto, las rentas imputadas se encuentran reconocidas expresamente a lo largo de la Ley del Impuesto a la Renta, como ocurre en los casos de las rentas fictas de predios no ocupados por el propio contribuyente o derechos sobre los 
mismos o la atribución de ingresos empresariales tratándose de servicios prestados a título gratuito ${ }^{19}$.

Finalmente, la ley recoge como teoría que delimita el concepto de renta gravada a los ingresos producto de "operaciones con terceros" según lo cual está afecto al impuesto cualquier beneficio obtenido como consecuencia de la actividad empresarial. Esta teoría es recogida en el literal c) del artículo 1 de la Ley y definida por el Reglamento de la Ley del Impuesto a la Renta ${ }^{20}$ como a aquella obtenida en el devenir de la actividad de la empresa en sus relaciones con otros particulares, en las que los intervinientes participan en igualdad de condiciones y consienten el nacimiento de obligaciones.

Tratándose del recargo al consumo no nos encontramos ante un supuesto de renta gravada con el Impuesto a la Renta empresarial, en la medida que éste no constituye propiamente un ingreso a cargo de la empresa que lo percibe al no tener libre disposición de estas cantidades y contabilizarlo como una "cuenta por pagar", asumiendo la obligación de pago a favor de sus trabajadores. Aún en el supuesto negado que el recargo al consumo sea considerado como un ingreso para la empresa, en principio no nos encontraríamos frente a un ingreso gravado con el Impuesto a la Renta, ya que este ingreso tiene un origen que nace de la voluntad del deudor tributario, sino que por ley dicho ingreso debe ser entregado a los trabajadores, situación que determina

${ }^{19}$ Con relación a las "rentas imputadas" la Administración Tributaria - SUNAT mediante el Informe $\mathrm{N}^{\circ}$ 090-2006-SUNAT/2B0000 emitido el 30 de marzo de 2006 señaló que: “... debe tenerse en cuenta que el primer párrafo del artículo $32^{\circ}$ del TUO de la Ley del Impuesto a la Renta ha incorporado una ficción legal mediante la cual se imputa una renta en el caso de prestación de servicios realizados a título gratuito; lo cual implica que la normatividad del Impuesto a la Renta ha incorporado dentro del campo de aplicación de dicho impuesto a los servicios prestados a título gratuito, atribuyéndole el carácter de renta gravada."

20 “Artículo 1.- ÁMBITO DE APLICACIÓN DEL IMPUESTO

A fin de determinar los ingresos comprendidos en el ámbito de aplicación del Impuesto a la Renta, se aplicarán las siguientes reglas:

...

g) La ganancia o ingreso derivado de operaciones con terceros a que alude el penúltimo párrafo del artículo 3 de la Ley, se refiere a la obtenida en el devenir de la actividad de la empresa en sus relaciones con otros particulares, en las que los intervinientes participan en igualdad de condiciones y consienten el nacimiento de obligaciones.

En consecuencia, constituye ganancia o ingreso para una empresa, la proveniente de actividades accidentales, los ingresos eventuales y la proveniente de transferencias a título gratuito que realice un particular a su favor. En estos casos, el adquirente deberá considerar la ganancia o ingreso al valor de ingreso al patrimonio.

El término empresa comprende a toda persona o entidad perceptora de rentas de tercera categoría y a las personas o entidades no domiciliadas que realicen actividad empresarial." 
que éste no se encuentre dentro de ninguna de las teorías recogidas en el ámbito de aplicación del Impuesto a la Renta.

En este mismo sentido, se pronunció la Administración Tributaria - SUNAT a través del Informe 049-2014-SUNAT/4B0000 del 14 de abril del 2014 señala que:

... los montos recibidos por los establecimientos de hospedaje, restaurantes y agencias de viaje, según corresponda, por concepto de recargo al consumo a que se refiere la Quinta DCF del Decreto Ley N. ${ }^{\circ} 25988$ y propinas para sus trabajadores, cuenten o no con comprobantes de pago que los sustenten, no tienen naturaleza de ingreso para estas empresas por cuanto no suponen un beneficio económico suyo sino de sus trabajadores.

Por lo anteriormente expuesto, el recargo al consumo para la empresa no califica dentro del concepto de renta producto, flujo de riqueza, rentas imputadas, ni mucho menos se trata de un ingreso proveniente de operaciones con terceros, motivo por el cual podemos establecer que dicho ingreso no se encuentra gravado con el Impuesto a la Renta empresarial, calificando este como uno inafecto ${ }^{21}$.

\subsubsection{Desnaturalización del recargo al consumo y su afectación al Impuesto a la}

\section{Renta Empresarial}

Habiendo establecido que en principio el recargo al consumo no constituye un ingreso gravado para la empresa que lo percibe y paga a sus trabajadores, merece especial interés el análisis referente a la calificación como renta gravada para la empresa del recargo al consumo cobrado por la empresa y no distribuido entre sus trabajadores.

Sobre el tema, existen escasas resoluciones emitidas por el Tribunal Fiscal que se pronuncian sobre la calificación de renta gravada del recargo al consumo en supuestos en los que no hay un pago efectivo a los trabajadores de la empresa.

Así, mediante la RTF $N^{\circ}$ 00419-1-2002 del 29 de enero de 2002, el Tribunal Fiscal determina que al no ser posible establecer que el monto reparado haya sido efectivamente pagado a terceros, ni que el mismo constituya un ingreso extraordinario para la recurrente, resulta necesario para acreditar el reparo que la Administración Tributaria revise los libros y registros contables, a efectos de sustentar la existencia del indicado ingreso extraordinario.

${ }^{21}$ A través de la Resolución $N^{\circ}$ 559-4-97 el Tribunal Fiscal define a la "inafectación" como una situación que no ha sido comprendida dentro del campo de aplicación del tributo, es decir, que está fuera porque no corresponde a la descripción legal hipotética y abstracta del hecho concreto (hipótesis de incidencia). 
Por su parte, mediante la RTF $\mathrm{N}^{\circ}$ 06251-1-2002 del 29 de octubre de 2002, el Tribunal Fiscal declaró que el recargo al consumo no constituye un ingreso extraordinario gravado con el Impuesto a la Renta, aun cuando se haya acreditado que dicho recargo haya sido abonado a terceros, siendo irrelevante que en algunos casos los beneficiarios de dicho recargo no mantuvieran relación contractual con la empresa que sustentaría las entregas.

En ese sentido, el Tribunal Fiscal es de opinión que en aquellos casos en los que la empresa no cumpla con la obligación de repartir el recargo en todo o en parte a sus trabajadores -casos muy comunes en la realidad- o aun cuando se pueda acreditar la entrega de dicho recargo a terceros distintos de los trabajadores de la empresa, ésta última no deberá reconocer como ingreso gravado con el Impuesto el recargo al consumo cobrado a los clientes.

Resulta del todo controversial el criterio asumido por el Tribunal Fiscal en las resoluciones materia de comentario, toda vez que, en la práctica se podrían presentar situaciones en las que la empresa haga cobro del recargo al consumo a sus clientes y se lo entregue a terceros vinculados a esta, tales como: locadores de servicios, accionistas o directores, sin que dicho ingreso se encuentre gravado con el Impuesto a la Renta empresarial. Esta situación, no solo determinaría un menor pago del Impuesto a la Renta, sino también del Impuesto General a las Ventas, como se desarrollará más adelante.

Expuesto lo anterior y en abierta discrepancia con los criterios asumidos por el Tribunal Fiscal, a continuación se exponen algunos supuestos en los que en nuestra opinión el recargo al consumo cobrado por la empresa a los usuarios de servicios y no pagado a los trabajadores si podría constituye un ingreso gravado con el Impuesto a la Renta de tercera categoría:

- Recargo al consumo no distribuido a los trabajadores y contabilizado por la empresa como una cuenta por pagar.

En este caso nos encontramos ante un supuesto en el cual la empresa cobra efectivamente el recargo al consumo, sin embargo, no hace entrega efectiva de dicho recargo a sus trabajadores, contabilizando el recargo como una cuenta por pagar a estos últimos. Resulta ser este el supuesto que comúnmente se presenta en la realidad, ya que muchas de las empresas que cobran el recargo al consumo 
no realizan la entrega efectiva de las sumas percibidas en calidad de recargo al consumo a sus trabajadores

En principio, el solo hecho de no pagar el recargo al consumo a los trabajadores no determina que dicho concepto califique como un ingreso gravado con el Impuesto a la Renta empresarial. Esto se sustenta en que, en el supuesto planteado la empresa le estaría dando a estas sumas el tratamiento de una “cuenta por pagar a favor de sus trabajadores" y el solo hecho de no pagarlo a los trabajadores por sí solo no lo convierte en un ingreso gravado para la empresa.

Para que el recargo al consumo sea considerado como un ingreso gravado afecto al Impuesto a la Renta empresarial, el trabajador acreedor del recargo al consumo debiera como condición perder el derecho al cobro del mismo, situación que únicamente se podría verificar con la declaración judicial de prescripción de la acción de cobro del recargo al consumo, momento en el cual a nuestro entender se produciría el reconocimiento como ingreso gravado con el Impuesto a la Renta empresarial.

Respecto del reconocimiento del ingreso, el artículo 57 de la Ley del Impuesto a la Renta señala que, las rentas empresariales se considerarán producidas en el ejercicio comercial en que se devenguen ${ }^{22}$.

Sobre lo que debe entenderse por "devengado", debemos anotar que las normas tributarias no han establecido una definición sobre tal concepto, razón por la cual debemos remitirnos a las Normas Internacionales de Contabilidad (en adelante NIC), la jurisprudencia y la doctrina.

El Marco Conceptual de las NIC señala lo siguiente:

Con el fin de cumplir sus objetivos, los Estados Financieros se preparan sobre la base de la acumulación o el devengo contable. Según esta base, los efectos de las transacciones y demás sucesos se reconocen cuando ocurren (y no cuando se recibe o paga el dinero u otro equivalente al efectivo), asimismo se registran en

\footnotetext{
${ }^{22}$ Con relación al concepto del devengado, el Tribunal Fiscal mediante la RTF Nº 02812-2.2006 señaló que: "El concepto del devengado implica que se hayan producido los hechos sustanciales generadores del ingreso y/o gasto y que el compromiso no esté sujeto a condición que pueda hacerlo inexistente, siendo que el hecho sustancial generador del gasto o ingreso se origina en el momento en que se genera la obligación de pagarlo o el derecho de adquirirlo, aun cuando a esa fecha no haya existido el pago efectivo, lo que supone una certeza razonable en cuanto a la obligación y a su monto."
} 
los libros contables y se informa sobre ellos en los estados financieros de los períodos con los cuales se relacionan.

A su vez, el Tribunal Fiscal emitió la RTF N 01515-4-2008 en la que señala lo siguiente:

...En este sentido, resulta necesario definir qué debe entenderse por "devengado" dado que las normas tributarias no lo han previsto, y de ello depende determinar cuándo, o en qué momento, es apropiado reconocer los ingresos como obtenidos. Al respecto este tribunal mediante la Resolución $\mathrm{N}^{\circ}$ 3557-2-2004, define el citado concepto de devengado citando a la siguiente doctrina:

Según REIG (1991) el ingreso devengado es:

... todo aquel sobre el cual se ha adquirido el derecho de percibirlo por haberse producido los hechos necesarios para que se genere. Correlativamente en cuanto a los gastos, se devengan cuando se causan los hechos en función de los cuales, terceros adquieren derecho al cobro de la prestación que los origina.

Asimismo, considera que el concepto de devengado tiene las siguientes características:

- Requiere que se hayan producido los hechos sustanciales generadores del ingreso o del gasto.

- Requiere que el derecho al ingreso o compromiso de gasto no esté sujeto a condición que pueda hacerlo inexistente al momento de cumplirse lo comprometido.

- No requiere actual exigibilidad o determinación, ni fijación de término preciso para el pago, puede ser obligación a plazo y de monto no determinado aún.

De otro lado, el párrafo 20 de la NIC 18, establece que cuando el resultado de una transacción que involucra la prestación de servicios puede ser estimado confiablemente, los ingresos asociados con la transacción deben ser reconocidos de acuerdo al grado de avance de la transacción a la fecha de balance general. El resultado de la transacción puede ser estimado confiablemente, cuando todas las siguientes condiciones se cumplan:

- el monto del ingreso pueda ser medido confiablemente,

- es probable que los beneficios económicos fluyan a la empresa, 
- el grado de avance de la transacción a la fecha de balance pueda ser medido confiablemente, $\mathrm{y}$

- los costos incurridos para la transacción y los costos para completar la transacción puedan ser medidos confiablemente.

Finalmente, la Administración Tributaria ha emitido el Informe $\mathrm{N}^{\circ}$ 321-2002SUNAT/K0000, en el que señala lo siguiente:

De otro lado, de acuerdo a la doctrina, en el sistema de lo devengado se atiende únicamente al momento en que nace el derecho al cobro, aunque no se haya hecho efectivo, es decir, la sola existencia de un título o derecho a percibir la renta, independientemente que sea exigible o no, lleva a considerarla como devengada y por ende imputable a ese ejercicio.

Como contrapartida, tratándose de gastos, el principio de lo devengado se aplica considerándoseles imputables (deducibles) cuando nace la obligación de pagarlos, aunque no se hayan pagado ni sean exigibles.

En consecuencia, para la Administración Tributaria, y de acuerdo a las normas tributarias, no bastará con acreditar el cobro efectivo y el no pago del recargo al consumo a los trabajadores para realizar una acotación por Impuesto a la renta, siendo necesario, en nuestra opinión, acreditar la pérdida del derecho a cobro por parte del trabajador, debiendo reconocer la empresa el ingreso gravado en el ejercicio en el que se produce esta condición.

\section{- Recargo al consumo no distribuido a los trabajadores y contabilizado por} la empresa como un ingreso.

La contabilización del recargo al consumo como un ingreso determina que la empresa adopte como propio este beneficio económico desde el momento de su cobro no procediendo a su contabilización como una cuenta por cobrar a favor de los trabajadores, situación que en buena cuenta determina el reconocimiento de un ingreso gravado con el Impuesto a la Renta.

A diferencia del supuesto anterior, el hecho de contabilizar al recargo al consumo como un ingreso no hace más que otorgar una certeza razonable respecto del reconocimiento del ingreso y como tal de un ingreso gravado con el Impuesto a la Renta empresarial. 
Como veremos más adelante, el hecho de no proceder con reconocer al recargo como un ingreso gravado con el Impuesto a la Renta, además de originar una contingencia en el Impuesto a la Renta, traerá contingencias también en el IGV al haber disminuido sin motivo alguno la base imponible de dicho impuesto.

\section{- Recargo al consumo contabilizado por la empresa como una cuenta por pagar y distribuido a personas distintas a los trabajadores.}

En este caso, nos encontramos ante su supuesto en el cual la empresa cobra el recargo al consumo y realiza pagos por dicho concepto a personas distintas a los trabajadores con los que no necesariamente guarda un vínculo laboral.

La entrega del recargo al consumo a personas distintas a los trabajadores supone una disposición efectiva de dicho recargo para una finalidad distinta a la establecida por ley, situación que, en nuestra opinión, determina el reconocimiento de un ingreso gravado con el Impuesto a la Renta empresarial.

Esta posición como vimos anteriormente, se encuentra recogida en diversas resoluciones emitidas por el Tribunal Fiscal, entidad que las reconoce como renta gravada al constituir un "ingreso extraordinario" producto del cobro del recargo al consumo.

Tal como manifestamos anteriormente, sustentar lo contrario implicaría aceptar que la empresa se encuentre facultada a deducir los gastos en favor de personal con los cuales no guarda un vínculo laboral (locadores de servicios, practicantes, entre otros) y no gravar con el Impuesto a la Renta empresarial los ingresos que sirvieron para el pago a dichos trabajadores.

Como resultado de lo antes expuesto, podemos establecer que el recargo al consumo, en principio, no constituye un concepto gravado con el Impuesto a la Renta ya que no constituye un ingreso propiamente dicho para la empresa que realiza su cobro, no obstante, existen determinados supuestos en los que por circunstancias atribuibles exclusivamente a los establecimientos de hospedaje y restaurantes el recargo al consumo si podría devenir en un ingreso gravado con el Impuesto a la Renta, situaciones que se presentan en los casos en los que se le decida dar un destino distinto del de reparto a los trabajadores. 


\subsubsection{Recargo al consumo e impuesto general a las ventas}

\subsubsection{Aplicación del recargo al consumo y determinación de la base imponible del impuesto general a las ventas}

Conforme a la norma que regula el recargo al consumo, éste resulta de aplicación únicamente en operaciones de prestación de servicios ofrecidos por establecimientos de hospedaje o expendio de comidas y bebidas y no en todas las operaciones que se encuentran dentro del ámbito de aplicación del Impuesto General a las Ventas ${ }^{23}$; entendiéndose por "prestación de servicios" de acuerdo al numeral 1 del inciso c) del artículo $3^{\circ}$ de la Ley del Impuesto General a las Ventas e Impuesto Selectivo al Consumo, aprobado por Decreto Supremo No 055-99-EF (en adelante la "Ley del IGV") a: "toda prestación que una persona realiza para otra y por la cual percibe una retribución o ingreso que se considere renta de tercera categoría para los efectos del Impuesto a la Renta, aun cuando no esté afecto a dicho impuesto".

Entonces, resulta claro que el recargo al consumo solo puede ser cobrado por los establecimientos de hospedaje o expendio de comidas y bebidas por sus operaciones de prestación de servicios, debiendo separar las operaciones de prestación de servicios respecto de las de venta de bienes y otras afectas al IGV para determinar el monto a repartir entre sus trabajadores.

Respecto de la determinación de la base imponible del IGV, Bravo Sheen y Villanueva Gutiérrez (1998) entienden por base imponible a:

La cuantificación del aspecto material de la hipótesis de incidencia. Si por ejemplo, realizamos la venta de un bien gravada con el IGV (aspecto material), la Base Imponible responderá a la siguiente interrogante: ¿sobre qué monto de dicha operación se deberá aplicar el 18\%? Como podemos observar, la respuesta necesariamente se

\footnotetext{
${ }^{23}$ De acuerdo al artículo 1 de la Ley del IGV se encuentran dentro del ámbito de aplicación del impuesto las siguientes operaciones:

"Artículo 1.- OPERACIONES GRAVADAS

El Impuesto General a las Ventas grava las siguientes operaciones:

a) La venta en el país de bienes muebles;

b) La prestación o utilización de servicios en el país;

c) Los contratos de construcción;

d) La primera venta de inmuebles que realicen los constructores de los mismos

e) La importación de bienes."
} 
reflejará en una cifra determinada, de allí que se afirme que la Base Imponible constituye la parte mensurable (susceptible de ser medida) sobre la cual se aplica la tasa o alícuota del Impuesto para obtener el Débito Fiscal de cada operación. (p. 55)

Sobre este punto, la norma que crea el recargo al consumo expresamente señala que el recargo no forma parte de la base imponible del Impuesto General a las Ventas.

En concordancia con esta norma, el artículo 14 de la Ley del IGV regula un tratamiento especial en cuanto a la determinación de la base imponible del IGV en operaciones en las que resulta de aplicación el recargo al consumo, vale decir, en operaciones de "prestación de servicios” al señalar que: “... En el servicio de alojamiento y expendio de comidas y bebidas, no forma parte de la base imponible, el recargo al consumo a que se refiere la Quinta Disposición Complementaria del Decreto Ley N ${ }^{\circ} 25988^{\prime \prime}$.

Conforme a lo anterior, esta regulación especial elimina toda posibilidad de aplicar el IGV sobre la suma del valor del servicio y el recargo al consumo, en contraposición con la regla general contenida en el inciso b) del artículo 13 de la Ley del IGV que señala que la base imponible del IGV se encuentra constituida por el total de la retribución en la prestación o utilización de servicios ${ }^{24}$.

En este mismo sentido se pronunció la Administración Tributaria a través del Oficio $\mathrm{N}^{\circ}$ 257-2003-2B0000 del 12 de setiembre de 2009 mediante el cual concluye que:

... el recargo al consumo, a que se refiere la citada Quinta Disposición Complementaria, que realicen los establecimientos de expendio de comidas y bebidas no forma parte de la base imponible del IGV, aun cuando esté consignado en el comprobante de pago respectivo, y que dicho recargo no deberá exceder del 13\% del valor del servicio que se presta.

\footnotetext{
${ }^{24}$ Según al artículo 14 de la Ley del IGV, el "valor de la retribución por servicios" estará determinado por la suma total que queda obligado a pagar el usuario del servicio, entendiéndose que esa suma estará integrada por el valor total consignado en el comprobante de pago de los servicios, incluyendo los cargos que se efectúen por separado de aquél y aun cuando se originen en la prestación de servicios complementarios, en intereses devengados por el precio no pagado o en gasto de financiación de la operación.
} 
En el siguiente ejemplo, se explica la forma de determinación de la base imponible en servicios en los que se incluye el recargo al consumo y la forma correcta en que debieran disgregarse los conceptos y emitirse el comprobante de pago ${ }^{25}$ :

$\begin{array}{llll}\text { Base imponible del IGV } & = & \text { S/ } & 100.00 \\ \text { IGV de ventas }(18 \%) & = & \text { S/ } & 18.00 \\ \text { Recargo al consumo }(13 \%) & = & \text { S/ } & 13.00 \\ \text { Precio de Venta } & = & \text { S/ } & \mathbf{1 3 1 . 0 0}\end{array}$

Este tratamiento especial en cuanto a la determinación de la base imponible del IGV en servicios en los cuales resulta de aplicación el recargo al consumo, resulta ser una herramienta interesante para que los establecimientos de hospedaje y restaurantes, en buena cuenta, puedan hacer uso del recargo al consumo para disminuir válidamente su IGV de ventas o débito fiscal.

En efecto, al establecerse el cobro del recargo al consumo en establecimientos de hospedaje y restaurantes manteniendo incluso, con la misma escala de precios, el sujeto del IGV disminuye la base imponible del impuesto al tener la posibilidad de incorporar hasta un $13 \%$ de recargo al consumo. Esta situación se aprecia en el ejemplo comparativo presentado a continuación:

\section{ESCENARIO I - restaurante que no realiza el cobro del recargo al consumo}

$\begin{array}{lll}\text { Base imponible del IGV } & = & \text { S } / 100.00 \\ \text { IGV de ventas }(18 \%) & = & \text { S } / 18.00 \\ \text { Precio de Venta } & = & \text { S/ } \mathbf{1 1 8 . 0 0}\end{array}$

ESCENARIO II - restaurante que si realiza el cobro del recargo al consumo Base imponible de ventas $=\mathrm{S} / 90.08$

\footnotetext{
${ }^{25}$ Sobre la forma de emisión del comprobante de pago, el Reglamento de Comprobantes de Pago, aprobado por Resolución de Superintendencia No 007-99-SUNAT, señala que tratándose de FACTURAS, éstas deberá contener el monto discriminado de los tributos que gravan la operación y otros cargos adicionales (como es el caso del recargo al consumo), en su caso, indicando el nombre del tributo y/o concepto y la tasa respectiva. Tratándose de BOLETAS DE VENTA y TICKETS SIN DERECHO A CRÉDITO FISCAL, el Reglamento de Comprobantes de Pago no exige que se señale el monto discriminado del impuesto u otros recargos, pudiendo contener el importe total de la operación incluido tributos y recargo.
} 


$\begin{array}{lll}\text { IGV de ventas }(18 \%) & = & \text { S } / 16.21 \\ \text { Recargo al consumo }(13 \%) & = & \text { S } / 11.71 \\ \text { Precio de Venta } & = & \text { S/ } \mathbf{1 1 8 . 0 0}\end{array}$

Conforme se verifica en el ejemplo anterior y teniendo en consideración que el recargo al consumo no forma parte de la base imponible del IGV, la implementación del recargo al consumo a partir del ESCENARIO I, con un porcentaje máximo del 13\% e incluso manteniendo el mismo nivel de precio final, determinó que en el ESCENARIO II se verifique una disminución efectiva del IGV de ventas en un $1.79 \%$ (casi dos puntos porcentuales), llevándolo de un $18 \%$ a un $16.21 \%$. Esta simulación incluso debe ser realizada tomando el promedio de IGV de compras en la empresa, a fin de establecer el impacto en el IGV por pagar en la empresa.

Si bien es cierto que, la implementación del ESCENARIO II en empresas en las que aún no se empieza a cobrar el recargo al consumo, supone el análisis de varios factores, tales como la disminución de los ingresos netos de la empresa, la contingencia laboral misma por la implementación del recargo al consumo, la reducción de remuneraciones de los trabajadores para reemplazar remuneraciones por recargo al consumo; en realidad, resultaría ser un importante ahorro en materia impositiva.

\subsubsection{Contingencias por la desnaturalización del recargo al consumo e impuesto general a las ventas}

Hasta aquí, hemos podido apreciar que en aquellas situaciones deseadas por la norma en las que el establecimiento de hospedaje o restaurante realiza el cobro del recargo y los distribuye entre sus trabajadores, no se presentarían mayores problemas en la determinación y pago del IGV. Sin embargo, en aquellas situaciones en las que la empresa no reparte todo o parte del recargo al consumo, desnaturalizando este beneficio o lo contabiliza como un ingreso de libre disposición o lo destina a una finalidad distinta, se generaría una contingencia tributaria en el IGV.

En efecto, según lo expuesto anteriormente la implementación del recargo al consumo en una empresa representa en la práctica un menor pago del IGV; sin embargo, el hecho que dicho recargo no sea distribuido entre los trabajadores además de 
determinar un ingreso gravado con el Impuesto a la Renta, deviene en una omisión al pago del IGV y la correspondiente multa por la comisión de la infracción ${ }^{26}$.

La afirmación anterior se explica por el hecho consistente en que el no reparto del recargo entre los trabajadores desnaturaliza la finalidad contenida en la norma de creación de dicho recargo, y en ese sentido, para la empresa éste último no representaría sino un ingreso que debió formar parte de la base imponible del IGV.






\section{CONCLUSIONES}

- El recargo al consumo tiene una naturaleza laboral desde sus orígenes, situación que conlleva que los aspectos relacionados a su exigibilidad, aplicación de intereses, plazo de prescripción deban regularse por las normas laborales.

- El recargo al consumo tiene la naturaleza de un beneficio económico laboral no remunerativo de libre disposición determinado por ley y que es pagado por los establecimientos de hospedaje y restaurantes a sus trabajadores por cuenta de los clientes de dichos establecimientos.

- Respecto de la forma de distribución del recargo al consumo y teniendo en consideración que su norma de creación no tiene regulación expresa sobre el tema, ésta se determinará, en primer lugar, por la voluntad de las partes al momento de acordar el cobro del recargo al consumo en los establecimientos de hospedaje o expendio de comidas. En ausencia de acuerdo expreso en la forma de distribución, el recargo al consumo debe ser distribuido por igual dividiendo el total del ingreso por este concepto entre el número total de trabajadores de la empresa.

- Aun cuando el ingreso percibido por concepto de recargo al consumo por los trabajadores no tenga naturaleza remunerativa, dicho ingreso si califica como una renta de quinta categoría afecta al Impuesto a la Renta al tener su origen en el trabajo personal.

- Los establecimientos de hospedaje y restaurantes deberán cumplir con la obligación de retener y pagar el Impuesto a la Renta respecto del recargo al consumo, al calificar dichos establecimientos como agentes de retención respecto de las rentas de quinta categoría que pagan a sus trabajadores.

- El recargo al consumo, no forma parte de la base imponible de las aportaciones a ESSALUD y ONP, puesto que dichas aportaciones se calculan en función a los que las normas laborales entienden por remuneración,

- El recargo al consumo no constituye un ingreso gravado con el Impuesto a la Renta empresarial, en la medida que éste no constituye propiamente un ingreso a cargo de la empresa que lo percibe al no tener libre disposición de esta suma y contabilizarla como una "cuenta por pagar", asumiendo así una obligación de pago 
a favor de sus trabajadores. No obstante, existen determinados supuestos en los que el recargo al consumo puede calificar como un ingreso gravado con el Impuesto a la Renta empresarial y que se presentan en casos en los que se declare prescrita la acción de cobranza por parte del trabajador, reconocimiento contable del ingreso por parte de la empresa y supuestos en los que el recargo al consumo es distribuido a personas distintas a los trabajadores desnaturalizando así este beneficio.

- El recargo al consumo no forma parte de la base imponible del IGV, sin embargo, en supuestos en los cuales el establecimiento de hospedaje o restaurante en los que no se reparte todo o parte del recargo al consumo desnaturalizando este beneficio o se contabiliza como un ingreso de libre disposición o se destina a una finalidad distinta, se generaría una omisión en el pago del IGV y la correspondiente multa por la comisión de la infracción. 


\section{RECOMENDACIONES}

A continuación detallaremos las recomendaciones:

- La emisión de una norma reglamentaria por parte del Ministerio de Trabajo y Promoción del Empleo con la finalidad de regular aspectos no señalados de manera expresa en la norma de creación del recargo al consumo, tales como criterios de distribución en caso de ausencia de acuerdo entre trabajadores y empleadores, plazo para el pago del beneficio, mecanismos de acceso a la información por parte de los trabajadores para la determinación de la cuantía, entre otros aspectos.

- La realización de acciones inspectivas por parte de la Superintendencia Nacional de Fiscalización Laboral - SUNAFIL a efectos de verificar el cumplimiento en el pago del recargo al consumo a favor de los trabajadores en establecimientos de hospedaje y de expendio de alimentos y bebidas, debiendo sancionar administrativamente la inobservancia de las obligaciones de pago del recargo al consumo.

- La realización de acciones de verificación y fiscalización a por parte de la Superintendencia Nacional de Administración Tributaria - SUNAT destinadas a revisar el cumplimiento en las obligaciones relacionadas al Impuesto a la Renta de quinta categoría de los trabajadores de establecimientos de hospedaje y restaurantes. Estas acciones de fiscalización deberán también realizarse tanto en el Impuesto a la Renta como en el Impuesto General a las Ventas con la finalidad de detectar omisiones en el caso de desnaturalización del recargo al consumo.

- La emisión de un precedente vinculante por parte del Tribunal Fiscal que modifique el criterio vertido por el Tribunal Fiscal a través de la Resolución ํㅜ 03669-3-2015 que precisa que no existe la obligación de retener el impuesto a la renta de quinta categoría por parte de los establecimientos de hospedaje y hoteles al no ser éstos los que pagan dicha renta al trabajador sino que trasladan la misma directamente de sus clientes. 


\section{REFERENCIAS}

Benavides Mansilla, J. (8 de octubre del 2012) Comisión de ilícitos en los restaurantes turísticos del Cusco que aplican el recargo al consumo Decreto Ley $\mathrm{N}^{\circ} 25988$. Recuperado de: http://javierbenavidesmancilla.blogspot.pe/2012/10/laactividadturistica-en-la-ciudad-del.html

Bravo Sheen, D., \& Villanueva Gutiérrez, W. (1998). La imposición al consumo en el Perú: Estudio teórico-práctico de la ley del impuesto general a las ventas e impuesto selectivo al consumo. Lima: Estudio Caballero Bustamante.

García Mullín, R. (1978). Manual del Impuesto a la Renta, Centro Interamericano de Estudios Tributarios (C.I.E.T.) - DOC No 872 Buenos Aires.

Obregón Sevillano, T. L. (2005) El recargo al consumo. Actualidad empresarial, (82), V6-V7.

Reig, E. J. (1991). Estudio técnico práctico de la ley argentina sobre impuesto a las ganancias, a la luz de la teoría general del impuesto a la renta. Buenos Aires: Macchi.

Toyama Miyagusuku, J. (2001) Remuneraciones, ventas y la Sunat. Themis. Revista de Derecho (42), $288-299$.

Villegas, H.B. (2003). Curso de finanzas, derecho financiero y tributario. (8va ed.). Buenos Aires, Argentina: Editorial Astrea de Alfredo y Ricardo Depalma 


\section{BIBLIOGRAFÍA}

Arce Ortiz, E. G. (2008). Derecho individual del trabajo en el Perú: Desafios y deficiencias (1a ed.). Lima: Palestra Editores.

Bravo Cucci, J. A. (2015). Fundamentos de derecho tributario (Quintán. ed.). Lima: Jurista Editores.

Carvalho, P. d. B. (2011). Teoría de la norma tributaría (1a ed.). Lima: ARA.

Elías Montero, F., \& Estudio Elías Mantero (noviembre, 1995). Actualidad laboral: La revista informativa laboral más antigua del Perú. (Noviembre 1995)

Elías Montero, F., \& Estudio Elías Mantero (abril, 2002). Actualidad laboral: La revista informativa laboral más antigua del Perú. (310)

Hirache Flores, L. (2013). Actualidad contable. Lima: Instituto Pacífico.

Montes Delgado, D. (18 de junio de 2014). Re: Recargo al consumo como ingreso de las empresas. [Artículo del Blog de Derecho y Empresa]. Recuperado de: http://cuestionesempresariales.blogspot.pe/2014/06/recargo-al-consumo-comoingreso-de-las.html.

Neves Mujica, J. (2012). Introducción al derecho del trabajo (2a ed.). Lima: Editorial PUCP.

Picón Gonzales, J. L. (2011). Deducciones del impuesto a la renta empresarial: ¿quién se llevó mi gasto?: la ley, la SUNAT o lo perdí yo. (3a. ed.). Lima: Dogma Ediciones.

Sanguineti Raymond, W. (2013). Derecho del trabajo: Tendencias contemporáneas. Lima: Grijley (460).

Sotelo, E. (26 de abril de 2011). Re: Cuitas del Recargo al Consumo. [Artículo del Blog de Enfoque Derecho]. Recuperado de: http://enfoquederecho.com/publico/tributario/cuotas-del-recargo-al-consumo/

Toyama Miyagusuku, J. (2015). El derecho individual del trabajo en el Perú: Un enfoque teórico-práctico (Primerá. ed.). Lima: Gaceta Jurídica.

Villegas, H. B. (1976). Los agentes de retención y de percepción en el derecho tributario. Buenos Aires: Depalma.

Villegas, H. B. (2002). Curso de finanzas, derecho financiero y tributario (8a act. y amp. ed.). Buenos Aires: Astrea. 
ANEXOS 


\section{ANEXO 1: Los trabajadores en hoteles y restaurantes tienen derecho a sueldos y salarios mínimos - Ley $\mathrm{N}^{\circ} 14701$, publicado el 13 de noviembre de 1963.}



ARTICULO $5 \%$ - Los trabajadores en hoteles, rostourantes y ramcs similares, sean empleados u obreros. tienen derecho al pago par sus empleadores de las remuneraciones vitales, sueldos y salarios minimos, previstos para los demás trabsjadores de la República.

ARTICULO 69 ,-Las remuneraciones. propinas y cualcuier otro ingreso do los trobajadores en hoteies. restaurantes y ramos similares no estón sujetos a descuento por concepto de fzltas, ruturas, pírdidas y muitos, saivo en los casos expresamente señalades par la ley. previa justificación dei mismo pronunciamiento de las sutoridades del trabajo.

ARTICULO 70 .-Los centros do trabajo habilitarán lugares de descanso para el personal que convenga en laborar despucis de las doce de la noche. por no desidir, a su elesción, retornar a su domicilio. En caso de la. borar despusés de las doce de la noche, el empleador le abonará los gastos de movilidad más las remuneraclones que le corresponda por trabaio nocturno.

ARTICULO $8^{\circ}$,-A los servidores que reciban alimentación en sus centros de trabajo, so les proporcionará asientos y luigar adecuads en las horas en que atiendan a esta necesidad.

ARTICULO $9 \%$-El empleador, en los centros de trabajo nocturno, proporcionará a sus servidores comida y cons.

ARTICULO 10?-Se sarantiza la waelta a su centro de trabajo de los servidores de les establecimientos que laberan por temporadas bajo la condicion del avisa qua se durá por escrito al principal una quincena antes de la reapertura del estabiecimiento.

ARTICULO $11^{\circ}$ _-LOS servidores de que trata esta ley recibirán, sin gasto para cllos, los uniformes y herramientas propias de su labor y tendrán derecho al liwado peristico de aquelios.

ARTICULD $12^{\circ}$ - Anualmente una Junta Reguladora, integrada paritariamente por representantes de em- 
pleadores y trabajadores de la industria, determinará los aumentos salariales que correspondan a la elevación del alza del costo de vida, en los lugares y centros de trabajo en que no haya sido posible arreglar un Pacto Colectivo.

En caso de desacuerdo intervendrán las autoridades del Ministerio de Trabajo y Asuntos Indigenas.

ARTICULO 13․-EI Touring $y$ Automóvil Club del Perú o la organización gubernamental turistica que lo reemplace promoverá, con la coo. peración de la Asociación Peruana de Hoteles. Restaurantes y Afines y la Federación Nacional de Trabajadores en Hoteles y Ramos Similares, la formación de un Centro Nacional de Aprendizaje de Servidores de Hoteles, tomando en cuenta la experiencia de las entidades internacionales del trabajo y de las organizaciones de esta indole. La Presidencia del Centro corresponderá a un representante del Ministerio de Trabajo y As'untos Indigenas y en su dirección deberán figurar delegados de las tres entidades mencionadas en este articulo.

ARTICULO 14\%.-Quedan derogadas todas las disposiciones que se cpongan a la presente ley.

Comuniquese al Poder Ejecutivo para su promulgación.
Casa del Congreso, en Lima, a los veintidós dias del mes de octubre de mil novecientos sesenta y tres.

JULIO DE LA PIEDRA, Presidente del Senado.

FERNANDO LEON DE VIVERO. Piesidente de la Cámara de Diputados.

CARLOS MALPICA, Senador Secretario.

LUIS F. RODRIGUEZ, Diputado Secretario.

Al señor Presidente Constitucional de la República.

\section{POR TANTO:}

Mando se publique y cumpla.

Dado en la Casa de Gobierno, en Lima, a lcs trece dias del mes de noviembre de mil novecientos sesenta y tres.

\section{FERNANDO BELAUNDE TERRY.}

\section{Carlos Pestana Zevallos}

Encargado de Trabajo y Asuntos Indigenas. 
ANEXO 2: Los hoteles, restaurantes y afines, regularizarán la aplicación del recargo del 3\% adicional al $10 \%$ de servicio sobre las facturas por alojamiento y consumo efectivamente pagadas por el consumidor - Ley $\mathrm{N}^{\circ} 16658$, publicado el 12 de julio de 1967.

\section{LEY $N^{\circ} 16658$}

Los hoteles, restaurantes y afines, regularizarán la aplicación del recargo del $3 \%$ adicional al $10 \%$ de servicio sobre las facturas por alojamiento $y$ consumo efectivamente pagadas por el consumidor.

EL PRESIDENTE DE LA REPUBLICA POR CUANTO . EL CONGRESO HA DADO LA LEY SIGUIENTE :

EL CONGRESO DE LA REPUBLICA PERUANA.

\section{HA DADO LA LEY SIGUIENTE}

ARTICULO $1^{\circ}$ - Los hoteles, restaurantes y afines regularizarán la aplicación del recargo del tres por ciento $(3 \%)$ adicional al diez por ciento $(10 \%)$ de servicio sobre la facturas por alojamiento y consumo efectivamente pagadas por el consumidor, el que se distribuirá como sigue : 
a).-El dos por ciento ( $2 \%)$ se des. tinará exclusivamente a cubrir los beneficios sociales de indemnizaciones, compensaciones por tiempo de servicios y las cuotas de jubilación y tim. bres por ambas partes, correspondientes al diez por ciento $(10 \%)$ de servicio que abona el consumidor a partir de la promulgación de la Ley 14701 con régimen independiente al del salario a cargo del empleador, cuyas obligaciones no se afectan en absolu. to. En el régimen del diez por ciento $(10 \%)$ de servicio, se establece la compensación cancelatoria anual por tiempo de servicios, con valor definitivo y no acumulativo a los beneficios futuros ni pasados, de acuerdo al promedio proporcional del porcentaje de servicio percibido durante el año. El empleador atenderá a la administración del porcentaje del servicio y al del recargo abonados por el consumidor en favor del sector laboral y liquidará la compensación anual por tiempo de servicios en el primer semestre del año subsiguiente. Los saldos se destinarán inicialmente a cubrir las obligaciones del régimen de servicio por los períodos anuales transcurridos y, posteriormente serán distribuídos entre los trabajadores de acuerdo al promedio proporcional de servicio recibido durante el año, sin que la percepción de estos saldos genere beneficios sociales ni obligaciones de ninguna clase.

b).-El uno por ciento (1\%) restante será depositado mensualmente por los empleadores en el Banco de la Nación, el que abrirá dos cuentas:

1)-A la cuenta 'Centro Nacional de Aprendizaje" de Servidores en Hoteles y Ramos similares se aplicará el medio por ciento $(1 / 2 \%)$, el que se destinará a la creación y el mantenimiento de dicho Centro, a cargo de una Comisión Organizadora y Directiva, constituída por un representante de la Corporación de Turismo del Perú, que la presidirá, un representante de la Asociación Peruana de Hoteles, Restaurantes y Afines y un representante de la Federación Nacional de Trabajadores en Hoteles y Ramos similares. Inicialmente y con preferencia, la ci. tada Comisión proporcionará de esta cuenta la suma destinada a la cons. trucción del local propio de la Federación Nacional de Trabajadores en Hoteles y Ramos similares, en el terreno al que se refiere la Ley $\mathrm{N}^{\circ} 15127$.

2) A la Cuenta Asociación Peruana de Hoteles, Restaurantes y Afines" se aplicará el otro medio por ciento $(1 / 2 \%)$ con el carácter de compensación por la labor administrativa que aporta el sector patronal para el cumplimiento de la presente ley, enten. diéndose que será de libre disposición de dicha Institución para que ésta atienda con mayor eficacia a sus fines estatutarios, con miras al mejor desarrollo y perfeccionamiento de los servicios, incluídos el otorgamiento de becas para capacitación y especialización del personal.

ARTICULO $2^{\circ}$-Los Hoteles, Restau rantes y Afines están obligados a pa. gar los porcentajes a que se refiere el Artículo $1^{\circ}$, desde el 29 de diciembre de 1966, en que se suscribió el Pacto Colectivo en el Segundo Departamen. to de Mediación de la Dirección General de Trabajo.

ARTICULO $3^{\circ}-$ La presente Ley sustituye para todos sus efectos, con la debida interpretación de propósitos y la habilitación de los medios para su cumplimiento, a los artículos Primero y Décimo Tercero de la Ley $\mathrm{N}^{\circ} 14701$.

ARTICULO $4^{\circ}$-Quedan derogadas todas las disposiciones que se opongan a la presente Lev.

Comuníquese al Poder Ejecutivo para su promulgación.

Casa del Congreso, en Lima, a los cinco días del mes de Junio de mil novecientos sesentisiete.

LUIS ALBERTO SANCHEZ, Presidente del Senado. 


\section{ANTONIO MONSALVE MORANTE, Presidente de la Cámara de Diputados TEODORO BALAREZO LIZARZA- BURU, Senador Secretario. \\ OSCAR EDUARDO CARBAJAL SO- TO Diputado Secretario. \\ Al señor Presidente Constitucional de la República. \\ POR TANTO : \\ Mando se públique y cumpla \\ Dado en la Casa de Gobierno, en Li- ma, a los seis dias del mes de junio de mil novecientos sesentisiete. \\ FERNANDO BELAUNDE TERRY}

Sandro Mariátegui 


\section{ANEXO 3: Modifican el art. 1 de la Ley 13771 modificado por el Decreto Ley $\mathrm{N}^{\circ} 10631$ referente al SENATI y CENASH - Decreto Ley 20631, publicado el 4 de junio de 1977.}



MODIRICAN ELL AR'S. 1\% DE LA LEY 13771 MODIFICADO POK BL DECRETO-LEY 19619 REBERENTE AL. SENATT Y CENASH DECRETO-LEY N" 20631 CONSTDERANDO:

Que de sonformidad con los Decretos.Le. yes 19619 y 20151, corresponde al Serviclo Nacional de Aprendizaje y Trabajo Yndusrrial. la aplicación $y$ control de la Calificación Profesional Extraordinaria of el Secror. Industria $y$ Comercio, hay Industrin $y$ Turismo:

Que con In crestión tel Ministerio de Comercio se ha moditicado la estructura orgánica y la dinnaminación del Sector Industria y Comercio por el de Industria y Turismo, poe to que es conveniente cambiar lu denominación det Servicio Nacional de Aprencllzaje y Trabujo Industrial -SENATY-, por la de Ser. vicio Nacional de Adiestramiento do Industra y Turlsmo -SENATT-;

Que por Lay 14701, se oncargó al Touring y Automóril Club del Pertù o a la Organizancion Gubernastental Turística que to recmpla. ce, con lą cooperación de otras entidades, la formación de un Cenrro Nacional de $A$ prendizaje de Servidores de Horeles, con el lin de propiciar el perfeccionamiento y la ca. pacitación de los trabajadores gue prestan servicios en la actividad hotelura y ramas similares:

Qus de acuerto con las recomendacioncs formulatas por la Comisión designada por Resolución Ministerial $N^{9}$ 086-74-IT-DS de 5 de Marzo de 1974, a la que se le encomendó estudiat la situacłón económica, académica, administrativa, laboral $y^{\prime}$ legal del Centro Na. cional de Aprendizaje de Servidores en Foteles y Ramos Similares $\rightarrow$ CENASH-a es necesario incorporar dicho Cenro al SENATI, tomando en consicleración In representación que en el Consejo Nacional de esta última Instirucion, deben rener los empleadores y trabajudores de la nctividad desarrollada en los es. tablecimientos de hospedaje $y$ ramos similares;

En uso de las l'aculfades tle que está investido, $y$

Con el voro uprobatorio del Consejo de Ministros:

Ha dado el Decreto-Loy siguiente:

Art. 1Y- Modíricase el Art. 1\% de la Ley N: 13771. modificado por el Decrero-Ley 19619, en In forma siguiente:
"Ari. 1"- El Servicio Nacional de Adies. tramiento de Inclustria y Turismo-SENA. TY-, es Instifución Pública Descentralizada del Sector Industria y Turismo y gora de per. sonerfa juridica".

Att. 2p- Incorporase a parkir de la vigenciu del presente Decreto-Ley, el Centro Nacionul de Aprendizuje de Servidores en Hoteles

y Ramos Similares -CDNASY - al Servicio Nacional de Adiestramiento de Industria $y$ Tur|smo -SENATI-, institucion encargada de impartir la Calificación Profesional Exrra. ordinsria on el Secror Industria y 'Turismo.

La incorporación a que se refiere el párrafo anterior, comprende al personal del CENASH conse: vando su mismo rógimen laboral y presupuestal, asi como a su parrimonio según Balance de Situación ul 30 de Abril de 1974,

Wit. 30- Ins metas $y$ pragramas de! CENASH se ejecutariln por el. SENATY, urilizando los Saldos de'los recursos asignados at CENASH en el Prosupuesto Bitenal 1973-1974 Ghé Minlsterio de Industria y Turismo. E Conscjo Nacionul clol SENATI estudiará, foroponderá los di.positivos iegules que se recquicra para el mejor cumplimiento tel preTrene Decreto-Les:

- Alt. 4:- Ampliase el Art. Q4 de la Ley 13771 moduficado por el Decieto-Ley $1961 \%$, con los Mnc/sos siguientes:

3) Un representante de las organizaciones lo enpieadores ste la actividad de estabiecimeicintos de hospedaje y afines; seleccionado Tor el Ministerio cio Industria y Turismo, pa. fo lo cual las organizaciones existentes pro. (joúdrán seis candidaros".

(45) Un representante de los Trabajadores yo Fsiablecimienros de Hospedaje y Ramos gsimilares, designado por el Ministerio de Trikfow jo"

Art. 5- Sustifúyase en los Decrotos-Leyes "y necivio", por los de "Industrín y Turismo".

Art. 6:- Durógase el Art. 13\% de la Ley Yy701 y tocias las disposiclones que se oponSiznis al presente Decreto-Ley.

Por Tanto: Mundo se publique y cumpla. Lima, a de Junio de 1974

Grąl. cle Div. EP. Juain Velasco Alvarado toral. de Div. EP. Edgardo Mereudo Jartín froie. Grat. FAP. Rolando Ghardl Rodriguex Mlee-Atmirante AP. Josd Ares Larco feonralmirante AP Alberto Jimónex de Kuelo. 


\section{ANEXO 4: Establecen régimen de distribución del recargo al consumo - Decreto Ley $\mathbf{N}^{\circ} 23128$, publicado el 11 de julio de}

1980.

\section{Establecen régimen do disturilbusión del necargo al consumo DECIRTO LEY NV 23128}

\section{EL PRESIDENTE DE LA RIPUBLTCA} POR CUANTO: guicunte:

El Cobicino Rewolucionario ha dado el Decreto - Ley si-

\section{EL GOBYHRNO REVOLUCIONARIO}

CONSIDERANDO:

Que, la vigencia de las Layes 14701 y 16658 , no han permi. tico una Justa $y$ equitativa distribución del porcentaje del $10 \%$ en el servicio que se aplice on los establecimientos de hospedaje, restaurantes $y$ similares:

Quo, en consecuenola, resulta necesarlo dítar las normas destinadas a su correcta interpretación y aplicación, con el objeto de lograr una mejot distribucion de dicho benefieto, en función del esfuerzo real y efectivo de los trabajadores:

Que, por Resolución Ministerial N* 0089-79 PM/ONAJ, se constibutyó una Comisión Muitisectorjal, encargada do estudiar y proponer las medidas a dícturise para el establecimiento de un nuovo réglmen de distribución del $10 \%$ de recargo al consu$\mathrm{mo}$, ha que ha cumplido con su objetivo:

En uso de las facuitades de que está investido; y

Con el voto aprobatorio del Consejo de Ministros:

In dado el Decreto Ley sigujente:

Artículo $1^{*}-$ Rl presente régimen de distribución del $10 \%$ del recargo al consumo sera establecido on forma obligatoria en todos los establecimlentos de hospedaje, resitaurantes, casinos de juego, bares, chitas, centros nocturnos, sociales y ramos similares $\mathrm{y}$ todas las empresas en general, que se dediquen a prestar sorvielos de alojamiento $y / \alpha$ expendio de comidas $y$ bebidas, efectuado en el establecimiento o fueru de el.

Artieulo $2^{*}-$ Los mencionados establecimientos aplicarán el recargo del $10 \%$ al consumo en forma obligatoria sobre el importe de las facturas que extiendan por alojamiento $\mathrm{y} / \mathrm{o}$ consumo, incluyendo servicios de lavanderia, estacionamiento, peluqueria y eatuna.

Artículo $3 v-$ Fl $10 \%$ de recargo al consumo sevá atstri. buido por el empleador entre todos los trabajiedores estables do la empresa, sean obretos o emploados, de la slgulente forms:

$-10 \%$ del $10 \%$ entro todos ios trabajadores obreros y empleados en partes iguales, teniendo en consideraclón los alas hombre laborados en forma real y efectiva por cada trabajador duyanto el mes: $y$

- IE $90 \%$ del $10 \%$ sera distrlbuldo por la empresa bajo el sistems de puntaje, tenlendo en consideración lit responsabili: dad, calificación, espectaljedud $\mathrm{y}$ otros factores detorminsutes, pura cuyo efecto se aplicará la Trabla de Puntaje, que figura 


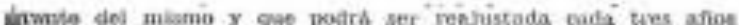

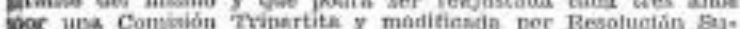
prema,

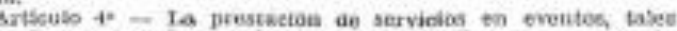

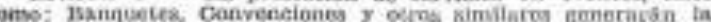

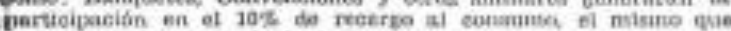
erd distribsuido de in alpuimule forma

$-40 \%$ dei $10 \%$ on pattes iguales unire Laskos las tribaja-

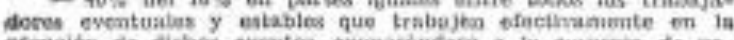



cas por Ley, y phosdo al flokima el evento:

- $65 \%$ del $10 \%$ entre todos ins tratiojadoves estables de

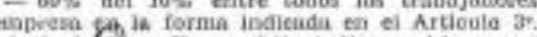

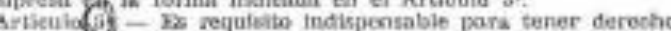
entaro del tesarso del 10 s al eonsumo, in prestación det traunjo en forma real $y$ efectivi, salio el tabo de vachrbones, in-

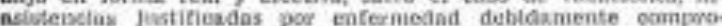
bada sceidentes de trabnju, descanso smmanat y licenein sindt.

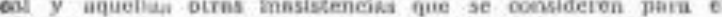
aleuso de renerd vasabomal oomo, dlas efoctros de trabajo

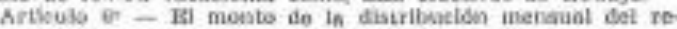

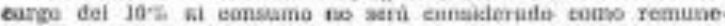

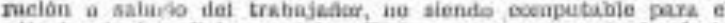

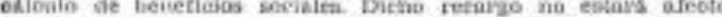

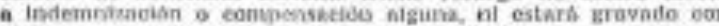

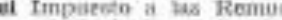

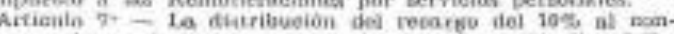







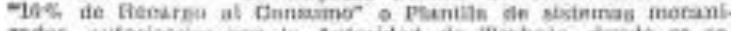





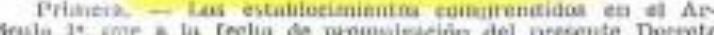





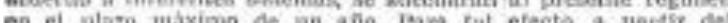



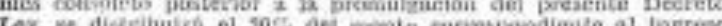

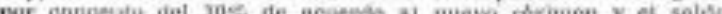









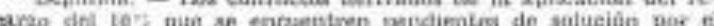



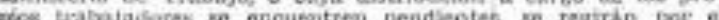

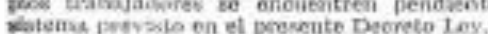



aderuartit $=$ tas disposionomes ded posento Decreto Lay.

\section{Dtsiessicton Vinat.}

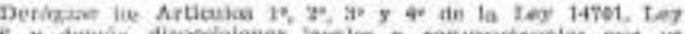

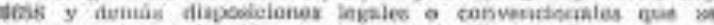



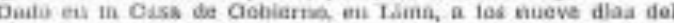
Se Jullo is int noveelentos echenta

Oenenil de Divisabe EP. FIRANCIBDO MORALEg BTrsev.

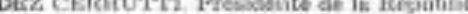





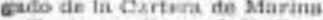


ae Arentaitia.

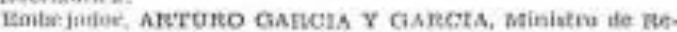

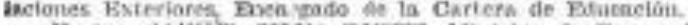

Duatur invizat BIIVA RUIETE, Mlmistso de Ecocomin y

Finknxs:

Vieesimirante AP., JOAOE DU BO18 ORRVASI, MSiniateo



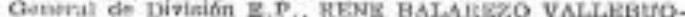

NA, Batsistio de Enerrin y Minas.

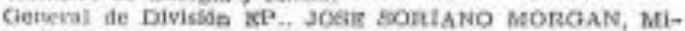

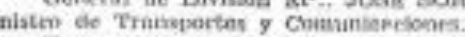

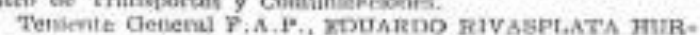

TADO, Minatro de sniud.

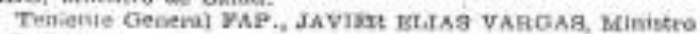
Trmbajo

Cenural de Brienda IRP, crant rogas cregro, Maiseno

Je Vivirnde Coustruecide,

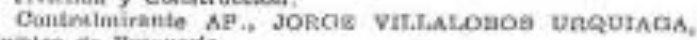

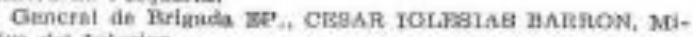

aistev elp Tutarior.



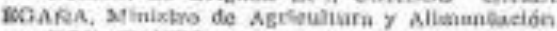
POE TANTO:

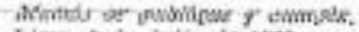

Lima. D da Julio be 1 bago.

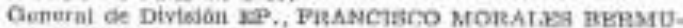

DEF CERAturTt

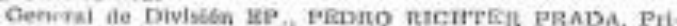

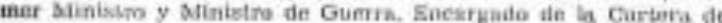

Marimat

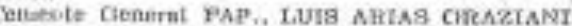


TABLA DE DISTRHBICLON DEL 10\% DE RECARGO AI. CONSLMO

\begin{tabular}{|c|c|c|c|c|c|c|}
\hline Puntaje a recibir & 10 Puntos & 8 Puntos & $6 \mathrm{P}$ untos & A Puntos & 2 Puntos & 1 Patoto \\
\hline $\begin{array}{l}\text { Oarros Ochzacio- } \\
\text { aales y Oaterarias } \\
\end{array}$ & $\begin{array}{l}\text { Also Nivel de } \\
\text { Especializadión }\end{array}$ & Especialización & Nivel Bâsico & Jefea de Mando Medio & Aprenalices & Ejecutivos \\
\hline Admintstracisu & 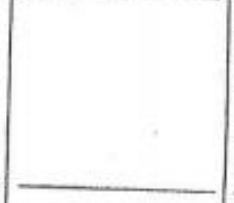 & $\begin{array}{l}\text { Contadores } \\
\text { Sectretarias } \\
\text { Kaurdistas } \\
\text { Programadores } \\
\text { Contadores } \\
\text { Cujeros } \\
\text { Procesadores } \\
\end{array}$ & $\begin{array}{l}\text { Vigilantes } \\
\text { Cobradores } \\
\text { Adicionistas } \\
\text { Ayudantes } \\
\text { Asistentes } \\
\text { Auxiliazes } \\
\end{array}$ & $\begin{array}{l}\text { Jefes de Personu1 } \\
\text { Jefes de RR.pp. } \\
\text { Jefes de Plgaduria } \\
\text { Jefen de Administra- } \\
\text { eión. } \\
\text { Jefes de Seguridad } \\
\text { Otros Jefes } \\
\end{array}$ & & $\begin{array}{l}\text { Gonerales } \\
\text { Administiadores } \\
\text { Directores da } \\
\text { Area }\end{array}$ \\
\hline Recepcibn & $\begin{array}{l}\text { Jete de Recepción } \\
\text { Jefe de Conserjes }\end{array}$ & $\begin{array}{l}\text { Recephifunistas } \\
\text { Ascensoriatais } \\
\text { Porteros } \\
\text { Cajeros } \\
\text { Conserjes } \\
\text { Telefonistas } \\
\text { Maleteros - Bo- } \\
\text { tones. } \\
\end{array}$ & $\begin{array}{l}\text { Choferes } \\
\text { Mengajeros } \\
\text { Ayudiantes } \\
\text { Asistentes } \\
\text { Auxiliares }\end{array}$ & $\begin{array}{l}\text { Asistentes Soeinles } \\
\text { Jefes de Caja } \\
\text { Jefes de Yacturación } \\
\text { Jefes de Reserva } \\
\text { Otros Jefes }\end{array}$ & & $\begin{array}{l}\text { Gerentes } \\
\text { Directores de } \\
\text { Area }\end{array}$ \\
\hline $\begin{array}{l}\text { Serviclo de Piso } \\
\text { y Lavanderia }\end{array}$ & Jefo de Piso & $\begin{array}{l}\text { Cusrteleros } \\
\text { Gobernantes } \\
\text { Axufatas } \\
\text { Mueamas } \\
\text { Lavsunderag } \\
\end{array}$ & $\begin{array}{l}\text { Ayudanles } \\
\text { Asistentes } \\
\text { Auxiliares }\end{array}$ & $\begin{array}{l}\text { Jefes de Lavanderia } \\
\text { Jeles de Roperia } \\
\text { Ama do Llaves } \\
\text { Otros Jeles } \\
\end{array}$ & Peones & $\begin{array}{l}\text { Gerentes } \\
\text { Directores de } \\
\text { Aroa }\end{array}$ \\
\hline $\begin{array}{l}\text { Restaurante, Bar } \\
\text { Y Codina }\end{array}$ & $\begin{array}{l}\text { Jefe de Bar } \\
\text { Burmans } \\
\text { Mattres } \\
\text { Chefts } \\
\text { Jefes de Panade- } \\
\text { ria } y / 0 \text { Pasteleria } \\
\end{array}$ & $\begin{array}{l}\text { Monos } \\
\text { Parrilleros } \\
\text { Plancheros } \\
\text { Cpeinoros } \\
\text { Fleladeros } \\
\text { Carniceros } \\
\text { Panaderos } \\
\text { Pescaderos } \\
\text { Cafeteros } \\
\end{array}$ & $\begin{array}{l}\text { Ravaplatos } \\
\text { Ayudantes } \\
\text { Asistentes } \\
\text { Auxiliares }\end{array}$ & $\begin{array}{l}\text { Jefes de Comidas y } \\
\text { Bebiclas } \\
\text { Jefes de Bnquetes } \\
\text { Jefes de Servicto do } \\
\text { Cafeteria } \\
\\
\end{array}$ & Pinches & $\begin{array}{l}\text { Gerentes } \\
\text { Direetores de } \\
\text { Area }\end{array}$ \\
\hline Ałmacén & & $\begin{array}{l}\text { Almaceneres } \\
\text { Bodegueros } \\
\text { Costureros } \\
\text { Sastros } \\
\end{array}$ & $\begin{array}{l}\text { Ayudantes } \\
\text { Asistentes } \\
\text { Auxillares }\end{array}$ & $\begin{array}{l}\text { Jefes de Almacén } \\
\text { Jefes de IBodega } \\
\text { Jefes de Compras } \\
\text { Otros Jefes } \\
\end{array}$ & - & \\
\hline Mrantenimiento & - & \begin{tabular}{|l} 
Fogoneiros \\
Meceinicos \\
Electrieistas \\
Plomeros \\
Pintores \\
Castiteros \\
Soldndores \\
Cerrajeros \\
Tormeros \\
Tappleeros \\
Ebanistas \\
Carpinteros \\
Jardineros \\
\end{tabular} & $\begin{array}{l}\text { Ayudiantes } \\
\text { Asistentes } \\
\text { Auxitiares }\end{array}$ & $\begin{array}{l}\text { Jefes de Manteni- } \\
\text { miento. } \\
\text { Jefes de Máquinas } \\
\text { Jefes de Calderos } \\
\text { Otros Jefes }\end{array}$ & Peones & Cerentes \\
\hline
\end{tabular}

\section{FOIMA DE CALCULO PATA SU DISTETBUCtoN}

Ge aumara el total de puntos asignados a todos los

b) El monto total del ingreso percibido durante el mes nervinifante del $10 \%$ do recargo al consumo, se dividira entre el total general de puritos, para obtenar of valos
de cada punto, El valor obten.

el nômero de puntes de cada punto se maltiplienra por el nâmero de puntos de enda trabajndor y su resultado 


\section{ANEXO 5: Tabla de Distribución del 10\% de recargo al consumo - Decreto Ley $\mathbf{N}^{\circ} \mathbf{2 3 1 2 8}$, publicado el 15 de julio de 1980.}

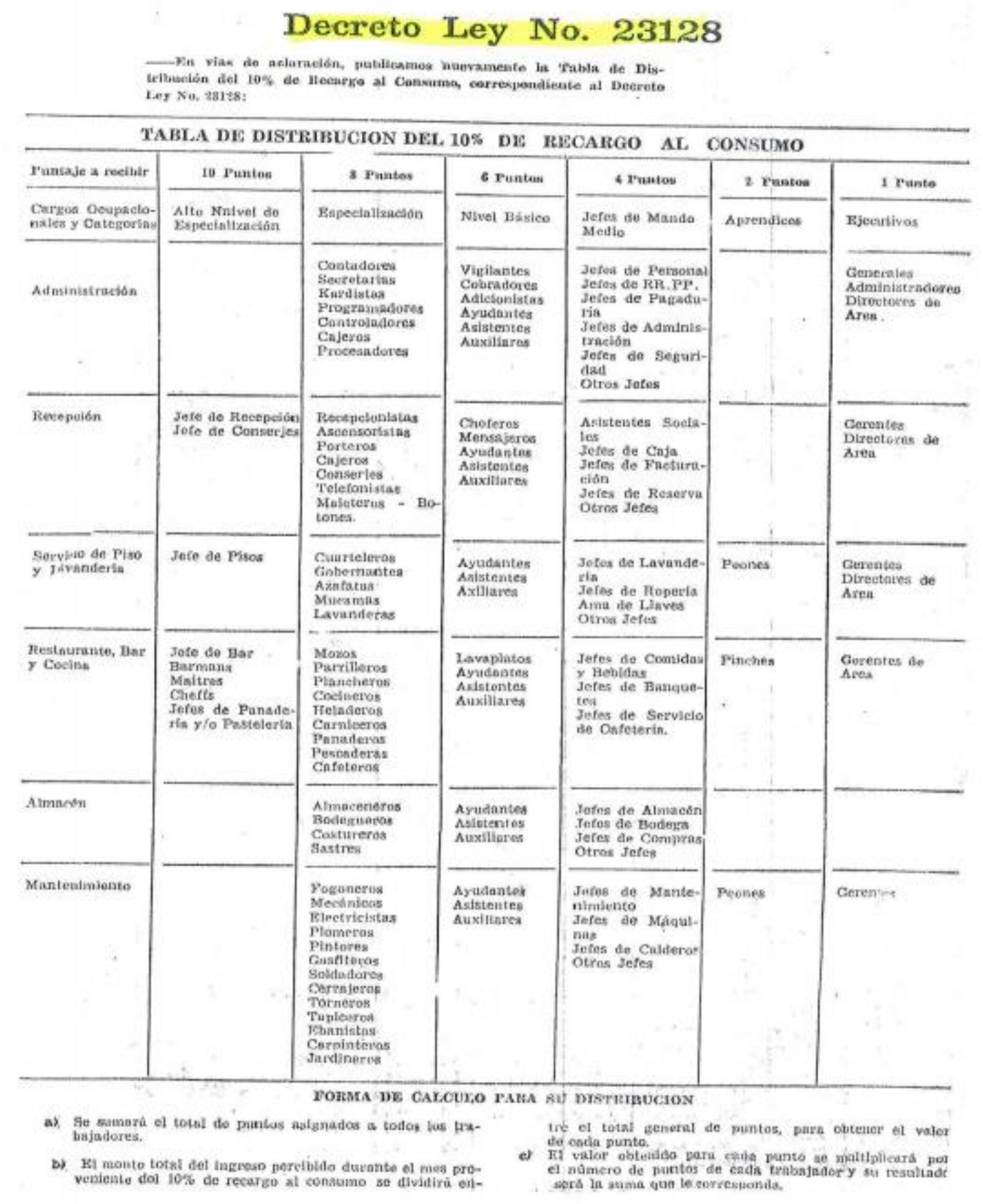




\section{ANEXO 6: Establecen un recargo único de 13 por ciento}

sobre el importe de facturas que extiendan establecimiento de hospedaje y/o expendio de bebidas, casinos de juego, bingo, bares, chifas, centros nocturnos, clubes sociales y ramos similares - Ley $\mathbf{N}^{\circ}$ 24896, publicado el 16 de octubre de 1988.

Establecen un recargo único de 13 por ciento sobre el importe de facturas que extiendan establecimientos de hospedaje y/o expendio de bebidas, casinos de juego, bingo, bares, chifas, centros nocturnos, clubes sociales y ramos similares.

LEX N: $24896(/)$

EL PRESIDENTE DE LA REPUBLICA

POR CUANTO

EL CONGRESO HA DADO LA LEY SIGUIENTE EL CONGRESO DE LA REPUBLICA DEL PERU; Ho dado la ley siguiente:

Artícalo 19- Establecese un recurgo único del 13\% sobre el importo de las tacturas que extienda todo estableoimlento do hospedaje y/o expendio de bebidas y comidas, talea como restaurantes, pote les, hostales, casinos tha juego, bingo, bares, chifas, centros nocturnos, clubes soclales y ramos zimilares.

Este recargo es aplicable al Integro de la factu. ración por todo servioio prestado de alojamiento y consumo, tncluyoudo los servictos aflines directamente eféctuados por or trabajador, como lavanderia, estacionamiento, pelugueris, siuns, telefonfa, banquetes, copvenciones y cualquier otro que pudiera realizar.
Articulo 2:-El 13\% señalado en el artículo pre. cedento, será distribuldó de la siguiento manera:

a) $11 \%$ sera entregado a los trabajadores de acuerdo a la tabla de porcents jes establecidos ér entegrato di a presente ley y formara part Integranto del salario y serviru para computar pagar las indernnizaciones $\mathrm{y}$ la jubilación del trabajador.

b) $2 \%$ servirá para el pago de la indemniza. cion cancelatoria anual y de las aportaciones al Fonto de Jubliación del I.P.S.S., correspondiente a $11 \%$ del recargo al consumo con retroactividad a la vigencia del Decreto Ley $\mathrm{N}^{*}$ 23128. El ssido Bi lo hublere se distribuirs de conformidad con 18 Tabla de Distribución referida en el artículo 6?

Artículo 3:-El empleador llevará un libró es. pecial autorizado por el Ministerio de 'Trabajo y Promoción Social, en el que se registrarán, en for. ma quincenal las distribuciones que so efectúen en aplicaclón de la presente ley.

El empleador otorgars, obligatoriamente, una copia de las facturas emitidas, al sindicato o comite sindical si lo hublera, 0 al trabajador que los re presente is no exdatiera en la empresa reprosenta. ción sindical.

Esta copia tiene carícter confidencial y solo po drá ser utilizada por los trabajadores o por la re presentación sindical en reclamaciones de carícte administrativo y/o judicial referidos al caso, bajo responsabilidad del trabajador o de la representa. ción sindical en caso do incumplirniento do este precepto,

Artículo 4: - La distribución del $11 \%$ refe rida en (el punto a) del artículo 29 se cumplirí en los 5 primeros días sigulentes a cade quíncena siendo requisito indispensable para su percepción, la prestación real y efectiva del servicio, cepcion, la prestacion real y efectiva del servicio, deradals por ley para el calculo del perfodo vacaderatals por ley para el calculo del periodo vaca-
clonal y del beneficio compensatorio por tiempo de serviclos, como dfas de trabajo.

Quedan excluidos del benefiolo mencionado en el artículo 19, los propletarios, accionistas, directores y el gerente que ejerce la representsción legal de la empresa. 
que se da por escrito al principal una quincena antes do la rebjertura del establecimiento.

Artleuto gan I a Federaclón Nacional de Tra. bajadores en Hoteles, Restaurantes y afines, acreditarán un representente en las instituciones del sector turisnia en donde existentes directorios.

Articulo: 10+- Declárase "Dia del Trabajador Hotelero", el 27 de Marzo do cada ar̉o, como dia laborable.

Articulo $11^{*}$ - Derógase ol Decreto Ley N. 23128 y las demás disposiclones que so opongan 8. 18 presente ley.

Articulo $12 \%$ - La presente loy entrará en $\mathrm{v}$ gencis al dia siguiente de su publicación.

\section{DISPOSICION TRANSITORIA}

Los empleadores descontaran del producto que genere el recargo del $11 \%$ correspondiente a la segunda quinsena del mes de diciembre, los siguientes porcentajes:

-9.5\%, a los obreros para la Federación Naclo. nal de Trabajadores en Hoteles y Ramos s.mila. res del Peru, que servird para la refacelon y equi. pamiento de su tocal institucional; $y$

- $0.5 \%$ a a los empleados para la Federación de Empleados en Hoteles $y$ afines, que sers inverti. do exclusivamente, en la adquisición e implementación de su sede instituctonal.

Y

Comunfquesé al Prestutente de la Republics pa. ra su promulgacion.

Casa del Congreso, en Luma, a los catorce dias del mes de Octubre de mil novecientos ochentiocho,

ROMUALDO BIAGGI RODRIGUE⿱一𧰨 Presl. dente del Senado.

hDOTOOR VARGas haya, Presidente de la Carmara de Diputados.

AN

EXO 7: $x$ PISOS: do lumpiera. RIA, CAFE

e de perso and $y$ otros

fe de reserPISO8:

de flestas. A. CAFETE

jefes de bo.

s.

Contadore: estrellas o iestrellas o do Jdentica mono de lis

precedan.

i horos dis.

a que se rd

hubilitarín

tue convan-

noclse, por

1 domicillo.

doce de lo

tos de mo.

correspon.

untacion a la de ocho Las $y$ lugenienden esta exclusiva us servido-

ce trabajo io que la n dek aviso 


\section{Aplicación de la Ley 24896 que establece recargo del $13 \%$ sobre importe de facturas - Decreto Supremo $\mathbf{N}^{\circ}$ 001-89-TR, publicado el 6 de enero de 1989.}

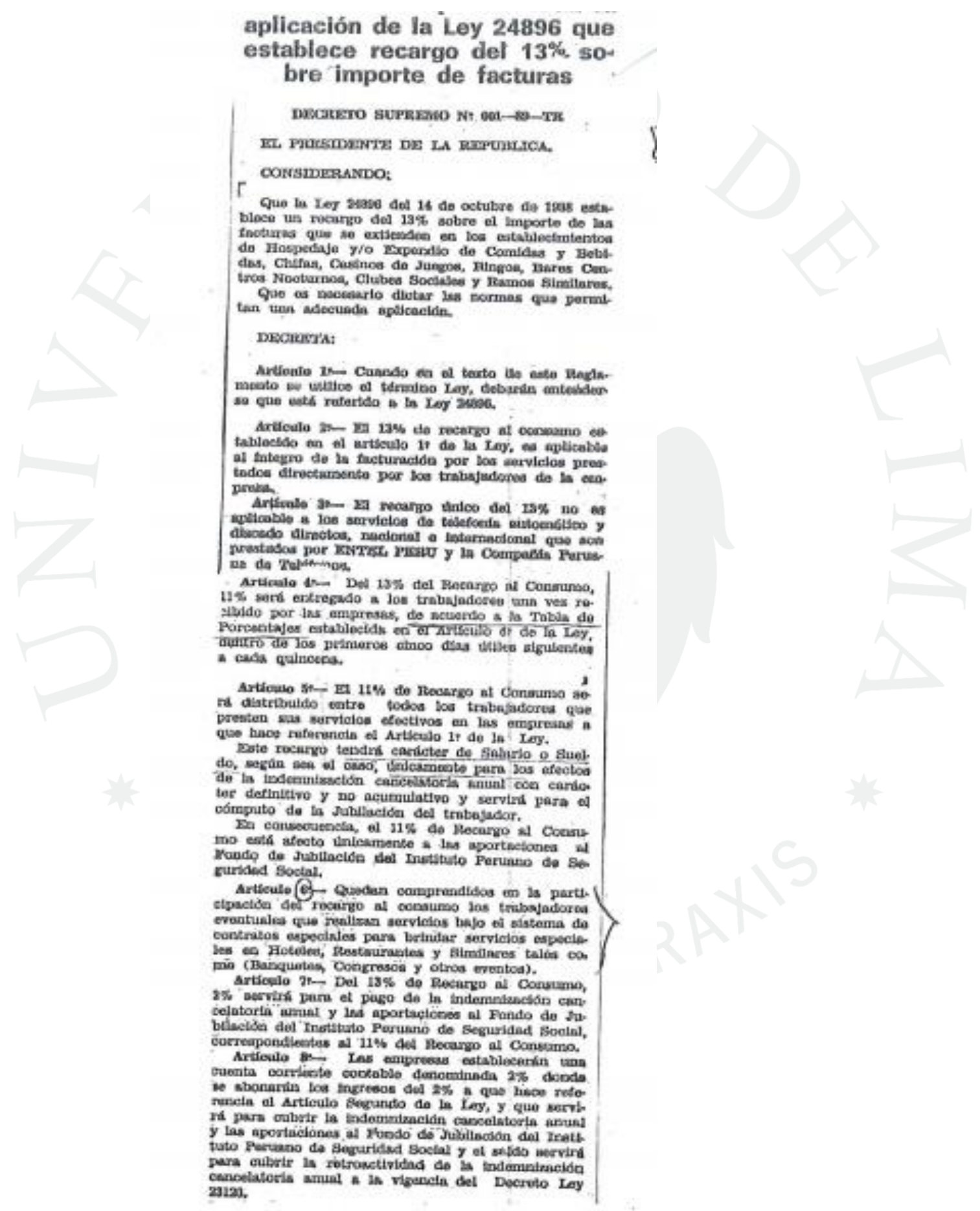


Artieula 91- Los empleadores frin cabrienda in

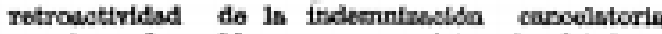
mual con los salisos que vam origtnando et s\%.

Artioalo 10:- Lés "spertén ál Farido do Juble. cSia del Instituto Peruna de Sesurided Soctal sa

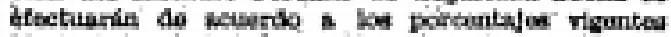
2. perlodo que correspoend cala aportacton. SI

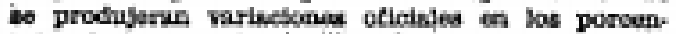
tajea do bos aportes, las sporticiones se handa ded. ewmente hestil per et manto que reesute de apulkir los porcentajed veccitesi is 17 do oetubre de 1968 , Artsculo ils Lod ipoirtes al Foedo do jublin.

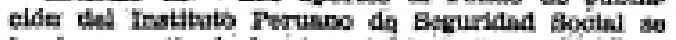

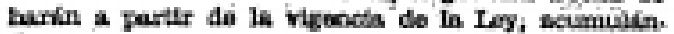
does para he trabajedorves las eportaciones que efectuaros durwute la viguencs da otros regimonea,


Juhllacide del Inotstuto Perisano de Bejuriflad Boéfar, al del empleador, int del trabafador,

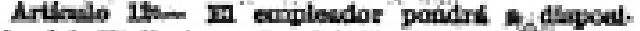

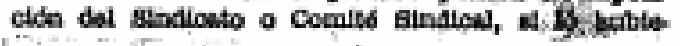

ra, 0 ded trabajador do la ampreas tise los repro. cante, el no mxistiebe repreoentacidn sindital, und oopts de lat tacturas eonitidas, taj mismas que eo. rin reviasasa dentro eded centro do trabajo.

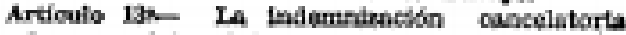
Rutal oon cartoter definitive y no acumalotlvo del

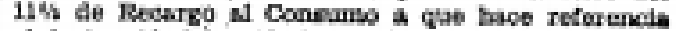
el (netao A) deil Artioulo is do is Ley, sa abonark. teniendo en consliseneiden at promedio proporto

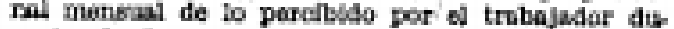

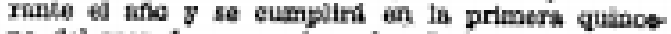
ra del mas de enero do cada aflo.

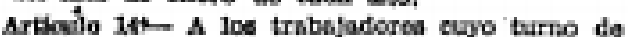
tribajo ocoching on el horarlo nocturno despuily de las 12 de lis nocke, el impleodor jes abonant gretos de movilidad para retornas a su docnictlio, rafs la rumuseracten que be corresponds en farzas proparclonal al tribejo necturno guo replicen.

Articulo 6 - tes empreses a gue hace referan cia el Artforlo it do is tey gua brinden survielo de alimentadidn, proporctonari 9 ats tribajadores,

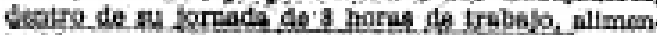
thetion; $y$ aquetlas que no bolnden vervicio de als meatectón lo pagarion el fastigredis sulmeditoto de nouerdo at ensto de vidis.

Artioula 14:- Qjedan sabelatentes de los regt

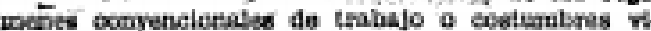

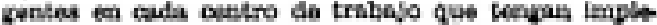
mescialo su proplo molemen de jocrasta de truba.


Articulo 87 de la Ley sa refiero a las centroa de

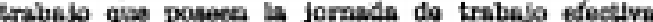
do $s$ horis $y$ grae aur obonrvala tamblin por lod euntroe de trabsjo a gue se netiere el Artioulo is


de is Iary.

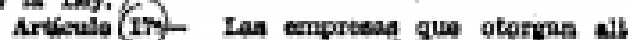
merciabion por contar con diche eervielo, fijertin

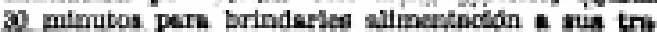

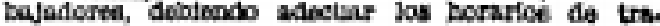
bajo pers curaplit dero tis.

Articelo 18:- IA Fodepectón Sinctonal de Tra bafadorea en Hoteles y Famoa 'Bimslares al Perd,

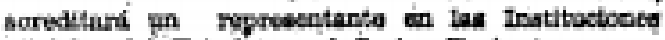
aticiales ded Tatado en al Sector Turiamio.

Articulo $19 \mathrm{t}-\mathrm{ic}$ descuento gub harda las ems. pieedores ait la pigunda gutincena dol moe de df

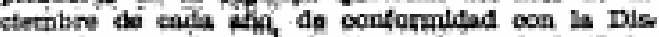
pontetide Tramitorin de in Iey is farror do la Feobraction Noctonal de Trabsefodores on Hoteles y lus mos Bimilares dol Fori $y$ la Pedaractón do Rmples.

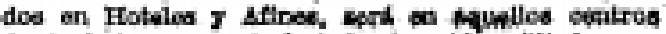
de trabajo, ouyos trabajadoria estal atiladas a

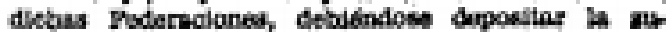
ma currespondiente on la Cuenta Banparla quo wo.

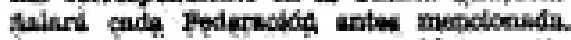

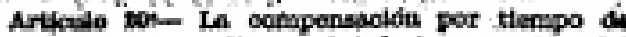

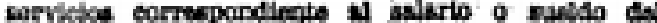

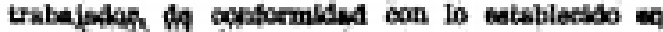

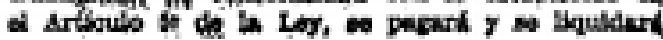

de conforraldad eon los roglibanas propica que tie. nera los trabujaderes obreros y emplestor, $y$ en oportudidedes que dichos recinsenes do establecen

\section{DISPOELCTONES THANSITOHLS}

PRIMETA_- La participaeión de loe trabajado tres thel Sector, do nouerda a la Tabla de Distribu cirio que seclala el Artfeulo bi, se hari por puntob $y$ Jns cargas qua ro figuran en in menciporata Ta. bla th la Ley ae catificarón por arablogh, timiendo en coscideradiden que en el rubro de 10 puntew se incluirda:

COCZNA-REPOSTEZIA Y PANADERIA-CAYETE

HA - CONTHOL DE SEEVICLOS:

Carniceros, heladeros, pescadaros y Jusueros.

MANTENIDLIENTO

Torneras, eerrojeras.

Reubro da E puntoe:

ICESTAPTHNYTS $\mathbf{x}$ Hates

Strwart.

COCINA-REPOSTETIA-PANADERTA Y CONTROL, DE SERVICIOS CONTHÓ IE SERVIGIOS Y DINTTNIMENTO:

Iamplstos-maquinistas.

Dado ej la Casa de:Croblezap, en Llma, s toe sets dias del mes de eosere de mil novecientos vebente y rueve.

ALALN GAleCtA PEREZ, Presidente Canstituclo nel do is Repsibtice.

OALST29 BODALCUEz CAMOOE, Kinstro de Tratas o y Proenocide Rectel. 